\title{
ENVIRONMENTAL JUSTICE IN THE EUROPEAN UNION: A CRITICAL REASSESSMENT
}

\author{
Davor Petrić*
}

\begin{abstract}
The paper discusses the concept of 'environmental justice' in the European Union, approaching it from the perspective of the centre-periphery gap in the EU, that is, the divide between the Member States from Western and Northern Europe on the one hand and Central and Eastern Europe on the other. It identifies distributive, procedural and corrective injustices that make the EU periphery, albeit less responsible for historical and contemporary environmental harms in Europe, bear the greater environmental burden, in addition to having less influence over environmental decision-making than the EU centre. The discussion is informed by the ideas that have emerged in US scholarship, especially regarding the concept of environmental justice itself, as well as the critical analysis of the (re)distributive effects of law and the identity critique of law. The paper concludes with a reflection on possible avenues for integrating environmental justice concerns into the EU legal and institutional framework in order to better address the centre-periphery gap and mitigate existing regional inequalities in environmental matters.
\end{abstract}

Keywords: environmental justice, European Union, centre-periphery gap, distributive injustice, procedural injustice, corrective injustice.

\section{Some introductory remarks}

Here is a question that may not ring a bell at first for a random European legal scholar: What is environmental justice? Of those who might know a thing or two about environmental law, my estimate is that nine out of ten would mention something regarding the Aarhus Convention, an international environmental treaty that regulates, among other things, access to courts (more on this later in the paper); hence, environmental justice. On the other hand, the term in the sense taken here would be

\footnotetext{
" Davor Petrić, Assistant Lecturer and PhD Candidate at the Department of European Public Law, Faculty of Law, University of Zagreb, orcid.org/0000-0001-7737-2150. Email: dpetric@pravo.hr. Research for this paper was completed under the project 'Novi hrvatski pravni sustav 2019' at the Faculty of Law, University of Zagreb. I am indebted to Professors Allyn D Kantor and Paul Mohai, and participants in the Environmental Justice seminar at the University of Michigan Law School (Winter Semester 2019), for many discussions that informed this paper. I am also grateful to Melita Carevic for reading an earlier draft of the text, to Mark Davies for his help with the language revision and copyediting, and to two anonymous reviewers for their critical remarks and tough questions that made me rethink my arguments. All errors remain mine. DOI: 10.3935/cyelp.15.2019.360.
} 
much more familiar to a US legal scholar. Such a scholar would probably come up with different definitions capturing the same or a similar idea which can be found in US academic and policy works.

So, I will also start with a definition, but, for the purposes of this paper, by defining the negation of environmental justice, or, in other words, environmental injustice. To my mind, this is a situation where a societal group which is the least responsible for environmental harms bears the greatest burden in dealing or living with those harms, at the same time having the least political clout or influence in decision-making on environmental matters.

In this sense, a couple of dimensions of environmental (in)justice become apparent: (i) distributive ones, which look at the distribution of resources ('goods' and 'bads', ie benefits and burdens), be it political, economic or environmental; (ii) procedural ones, which examine the institutional voice and access to decision-making; and (iii) corrective ones, which observe access to legal remedies to address environmental harms. Having these three dimensions as a conceptual framework, I will focus on the European Union (EU) and ask whether any kind of environmental injustice occurs in its legal and political system.

Before this, a word on the background to this question: what are the ideas that I will be working with?

First, environmental justice itself. The idea and concept come from the USA. There, it has attracted substantial attention in activist, academic and political circles from the late 1980s onwards. Much has been written on the historical and contemporary developments in the field of environmental justice, and here I will provide a brief summary.

The origins of the environmental justice movement are found at the grassroots level across the USA. The movement built upon the 1960s' Civil Rights Movement and the 1970s' burgeoning federal environmental laws, tying together concerns for social justice, human rights and protection of the environment. ${ }^{1}$ What became obvious was that environmental regulations and policies disparately impacted - irrespective of discriminatory intent - poor and deprived communities and marginalised

\footnotetext{
1 Kelly D Lynn, 'Seeking Environmental Justice for Cultural Minorities: The South Lawrence Trafficway of Lawrence, Kansas' (2003) 12 Kansas Journal of Law and Public Policy 224. For a fine overview of legal and policy developments in the field of environmental justice in the USA, see Jamie Vickery and Lori M. Hunter, 'Native Americans: Where in Environmental Justice Theory and Research?' (2014) Institute of Behavioral Science, University of Colorado, Boulder, Working Paper Population Program POP2014-04 1; also, Alice Kaswan, 'Environmental Justice: Bridging the Gap Between Environmental Laws and "Justice" (1997) 47(2) American University Law Review 221.
} 
racial minorities (mostly African Americans). ${ }^{2}$ It should, however, also be noted that there was (or still is) some scholarly disagreement regarding the underlying drivers of environmental inequalities in the US: whether they can be ascribed more to (direct or indirect) racial (hence the term environmental racism) ${ }^{3}$ or socio-economic factors (hence, environmental classism).

The high watermark of the movement came in 1987 with the publication of the report Toxic Wastes and Race in the United States. ${ }^{4}$ This study proved that locations of hazardous waste sites and polluting industries across the US corresponded to the racial (predominantly) and social characteristics of the surrounding neighbourhoods. ${ }^{5}$ A parallel struggle in the political arena culminated with President Clinton's Executive Order No 12898 entitled "Federal Actions to Address Environmental Justice in Minority Populations and Low-Income Populations”. ${ }^{6}$ Although commendable in language, ${ }^{7}$ Executive Order 12898 was not legally binding or judicially enforceable. ${ }^{8}$ Nevertheless, it did lead to some

2 See David J Galalis, 'Environmental Justice and Title VI in the Wake of Alexander v Sandoval: Disparate-Impact Regulations Still Valid Under Chevron' (2004) 31(1) Boston College Environmental Affairs Law Review 62-63, who argues that 'poor, minority communities are exposed to a disproportionately greater share of environmental hazards than affluent, Caucasian neighborhoods - not because of invidious racism, but as a result of neutral decisions made within intrinsically biased decision-making structures' (emphasis added). Furthermore, Galalis notes that 'environmental decisions are rarely made today with overt discriminatory animus. Rather, it is an economically, politically, and socially entrenched reality that these "blind" decisionmaking processes, left to themselves, will subject poor, minority communities to a disparate share of environmental harm as compared to surrounding affluent, Caucasian neighborhoods' 101 (emphasis added).

3 David Schlosberg, 'Theorising Environmental Justice: The Expanding Sphere of a Discourse' (2013) 22(1) Environmental Politics 39: 'Environmental justice wasn't simply about establishing the fact that more environmental bads and risks were being put on minority communities - it endeavoured to explore the question of why those communities were devalued in the first place. [...] The practice, and experience, of racism has been at the heart of environmental justice discourse in the United States [...]'.

4 Commission for Racial Justice, Toxic Wastes and Race in the United States: A National Report on the Racial and Socio-Economic Characteristics of Communities with Hazardous Waste Sites (United Church of Christ 1987).

5 This situation has not improved but rather deteriorated, as documented in the follow-up report by Robert D Bullard and others, Toxic Wastes and Race at Twenty 1987-2007 (United Church of Christ 2007).

659 Fed Reg 7629 (16 February 1994).

7 Section 1-101 reads: 'To the greatest extent practicable and permitted by law [...] each Federal agency shall make achieving environmental justice part of its mission by identifying and addressing, as appropriate, disproportionately high and adverse human health or environmental effects of its programs, policies, and activities on minority populations and low-income populations [...]'. See also Section 1-103 (mandating the development of agency-wide environmental justice strategies) and Section 2-2 (requiring agencies' inclusive and non-discriminatory operation in environmental matters).

8 Section 6-609: 'This order is intended only to improve the internal management of the executive branch and is not intended to, nor does it create any right, benefit, or trust responsibility, substantive or procedural, enforceable at law or equity by a party against the 
policy improvements: for instance, the Environmental Protection Agency (EPA) nowadays incorporates environmental justice principles in all its programmes and publishes Annual Environmental Justice Progress Reports; ${ }^{9}$ the Department of the Interior and some other federal agencies have adopted Environmental Justice Strategic Plans; ${ }^{10}$ the Council on Environmental Quality has issued guidelines for federal agencies on how to address environmental justice concerns when implementing and administering the National Environmental Policy Act, ${ }^{11}$ etc.

Recently, environmental justice has been spreading throughout the world, slowly gaining ground on the other side of the Atlantic, too. ${ }^{12} \mathrm{How}-$ ever, it has been noted that environmental justice in Europe has different connotations due to the continent's historical-cultural and legal-institutional peculiarities. Thus, Laurent explains:

United States, its agencies, its officers, or any person. This order shall not be construed to create any right to judicial review involving the compliance or noncompliance of the United States, its agencies, its officers, or any other person with this order'.

9 EPA, Office of Environmental Justice, available at <www.epa.gov/environmentaljustice/ annual-environmental-justice-progress-reports> accessed 28 October 2019. EPA has also established the Office of Civil Rights for (among other things) individual complaints alleging a discriminatory disparate impact suffered from actions by recipients of the EPA's financial assistance.

10 Department of the Interior, Office of Environmental Policy and Compliance, available at $<$ www.doi.gov/oepc/resources/environmental-justice> accessed 28 October 2019; Department of Agriculture, US Forest Service, available at <www.fs.fed.us/research/urban/environmental-justice> accessed 28 October 2019; Department of Agriculture, US Farm Service Agency, available at <www.fsa.usda.gov/programs-and-services/environmental-cultural-resource/environmental-justice/> accessed 28 October 2019. For a report on agency approaches to incorporating environmental justice into their programmes, see Environmental Justice Interagency Working Group, 'Promising Practices for EJ Methodologies in NEPA Reviews' (March 2016) available at <www.epa.gov/sites/production/files/2016-08/documents/nepa_promising_practices_document_2016.pdf> accessed 28 October 2019.

11 Council on Environmental Quality, 'Environmental Justice: Guidance under the National Environmental Policy Act' (10 December 1997) 21 available at <https://ceq.doe. gov/docs/ceq-regulations-and-guidance/regs/ej/justice.pdf> accessed 28 October 2019: 'Agencies should apply, and comply with, this guidance prospectively. [...] This guidance is intended to improve the internal management of the Executive Branch with respect to environmental justice under NEPA'.

12 Pioneering works emerged during the 2000s in the UK, such as the work of Kevin Dunion, Troublemakers: The Struggle for Environmental Justice in Scotland (Edinburgh University Press 2003). For Europe-wide studies, particularly significant was Steve Pye and others, 'Addressing the Social Dimensions of Environmental Policy: A Study on the Linkages Between Environmental and Social Sustainability in Europe', AEA Energy and Environment Report completed for the European Commission's Directorate-General Employment, Social Affairs and Equal Opportunities (2008), which found 'evidence which suggests that the social distribution of environmental quality is unequal, and often biased against poorer or socially excluded groups, ie such groups are more likely to live in areas of poorer environmental quality than other groups' (iii). 
Europeans highlight the social conditions producing injustices while Americans insist on the racial dimension of discriminations and exclusion from decision-making process that ethnic groups suffer. [...] The general difference in underlying philosophies of public policy is hardly surprising: the US approach traditionally recognizes the universality of natural rights granted to individuals and aims at curbing discriminations faced by them in exercising those rights, while continental European countries usually focus on correcting the social processes that produce situations of inequalities. ${ }^{13}$

So, the argument is that some of the key differences include: the lack of a European equivalent to the US Civil Rights Movement that is seen as the predecessor of the environmental justice movement; the different history and contemporary nature of Europe's racism; and the legal and policy approach to social issues that is somewhat more formalist in Europe and more substantive in the US (the question of formal $\mathrm{v}$ substantive justice is taken up later in the paper).

Nevertheless, one thing is becoming clear by now: much as in the USA, European policymakers and scholars have realised that "challenges to equality and fairness in the environmental domain are many and growing within the European Union'. ${ }^{14}$

The second idea that informs my discussion, more generally, relates to the comparison between the US and the EU. One may wonder whether there is any use in relying on American academic or policy concepts and approaches in analysing Europe-centred problems. This, hopefully, should not require much explanation: US-EU comparisons are a frequent topic for (especially, but not exclusively) comparative constitutionalists and federalism scholars, whereas American legal and political experiences have for a long time been a source of inspiration to a nascent European integration project. Many legal scholars have therefore compared different policy areas and doctrinal developments in the two bodies politic. ${ }^{15}$ Here, similarly, in analysing the environmental justice issues in the EU, I rely on the concepts that were originally proposed in US scholarship.

The third idea (or group of ideas) that this paper greatly benefits from concerns the critique of law: the ideas introduced by US schools of legal

\footnotetext{
13 Éloi Laurent, 'Issues in Environmental Justice Within the European Union' (2011) 70 Ecological Economics 1848-1849 (footnotes omitted, emphasis added); also, Éloi Laurent, 'Environmental Justice and Environmental Inequalities: A European perspective' (2010) OFCE/Sciences-Po Working Paper No 2010-05 1.

14 Laurent, 'Issues in Environmental Justice Within the European Union' (n 13) 1846.

15 For illustration, see a recent work by Daniel Halberstam, “'A People for Certain Purposes”: On the History and Philosophy of Federalism(s) in the United States and Europe' (2018) University of Michigan Public Law and Legal Theory Research Paper Series, Paper No 619, 3.
} 
thought that subsequently 'spilled over' to Europe. More specifically, the way American Legal Realists, the Critical Legal Studies (CLS) movement and identity critiques understood law and approached it has gradually gained ground in European legal scholarship. These ideas, addressing more critically the social functions of law and the policy effects it produces, will underlie my approach even where I am not explicit about it. Here I will highlight only the main propositions that I find inspirational.

Both legal realism and the CLS movement ('crits') were deeply sceptical of

virtually all of [legalist and legal formalist] various claims: the claim that law is distinct from politics, the claim that legal analysis must and can be objective, the claim that much of our received legal universe is grounded in some sort of necessity, the claim that law proceeds and evolves in more or less rational way, and, most important, the claim that one can find a meaning or a manageable range of meaning in legal texts, and that it is therefore possible to think of the legal enterprise as involving the fair application of agreed upon pre-existing rules. ${ }^{16}$

Rejecting these propositions, CLS scholars have further argued that law is a social construct and as such fundamentally indeterminate. Thus, '[t]he same body of law, in the same context, can always lead to contrary results because law is indeterminate at its core, in its inception, not just in its applications'. ${ }^{17}$ Moreover, the law is never neutral or objective since '[l]egal forms and practices are political products that arise from the struggles of conflicting social groups that possess very disparate resources of wealth, power, status, knowledge [...] and organizational capability'. ${ }^{18}$ Also, the law serves the interests and purposes of those in power:

discourses of legal and technical rationality, of rights, consent, necessity, efficiency [...] are of course discourses of power [...] they are discourses that [...] in habitual practice tend to express the interests and the perspectives of the powerful people who use them. ${ }^{19}$

Reading these critiques of law, I cannot but think of them as the intellectual brethren of the environmental justice movement that fuelled and helped to structure the latter's critique of environmental inequalities in the USA. In parallel to this, many legal scholars recently started

\footnotetext{
16 Stephen E Gottlieb and others (eds), Jurisprudence Cases and Materials: An Introduction to the Philosophy of Law and Its Applications (Third Edition, Carolina Academic Press 2015) 365-366 (emphasis added).

17 Robert W Gordon, 'Critical Legal Histories' (1984) 36 Stanford Law Review 114 (emphasis added).

18 Gordon (n 17) 101.

19 Robert W Gordon, 'Unfreezing Legal Reality: Critical Approaches to Law' (1987) 15(2) Florida State University Law Review 199 (emphasis added).
} 
adopting the same approach in analysing European law. ${ }^{20}$ Their insights and observations are built upon in this paper.

With this remark I close (rather convincingly, I hope) the circle of three ideas - environmental justice, a US-EU comparison, the critique of law - which I will combine and work on in the remainder of this paper.

\section{Environmental (in)justice(s) in Europe: where to look for them?}

There are at least three ways to approach the question of environmental (in)justice(s) in or involving Europe. ${ }^{21}$

First, one might address environmental injustice at the global level and look into the North-South divide, an ever-widening gap between the developed and developing world. For instance, Carmen Gonzalez noted that ' $[t]$ he primary cause of global environmental degradation is the unsustainable consumption of environmental resources by the most economically privileged, most of whom reside in the global North'. ${ }^{22}$

The landmark 1992 United Nations Framework Convention on Climate Change (UNFCCC) also recognised the developed (industrialised)

20 See, as an example, Tamara Perišin and Siniša Rodin (eds), The Transformation or Reconstitution of Europe: The Critical Legal Studies Perspective on the Role of the Courts in the European Union (Hart Publishing 2018).

${ }^{21}$ Laurent (n 13) 1848 recognised 'two dimensions [that] co-exist: a first dimension has to do with the important ecological debt the European Union has been accumulating at least since the industrial revolution vis-à-vis poor and developing countries in terms of carbon budget and resources use (global environmental justice); the second dimension regards intra and inter-generational aspects of environmental justice within the European Union (local, national and regional environmental justice)'. A similar approach to the question of economic inequalities and injustice has been proposed by Tamara Perišin and Sam Koplewicz, 'Blame it on Brussels: EU Law and the Distributive Effects of Globalisation' (2018) 14 Croatian Yearbook of European Law and Policy VII-VIII: 'In the EU context, there are in fact three perspectives [on economic inequality]: inequality between EU citizens and third country nationals, inequality between the EU centre and its periphery, and inequality within a single Member State'.

22 Carmen G Gonzalez, 'Environmental Justice and International Environmental Law' in Shawkat Alam, Md Jahid Hossain Bhuiyan, Tareq MR Chowdhury and Erika J Techera (eds), Routledge Handbook of International Environmental Law (Routledge 2013) 78ff: 'Twenty per cent of the world's population consumes approximately 85 per cent of the planet's timber, 70 per cent of its energy, and 60 per cent of its food. This population is also responsible for more than 90 per cent of the world's annual production of hazardous waste, some of which is exported to Southern countries and contributes to illness and widespread environmental harm. [...] While the affluent reap the benefits of unsustainable economic activity, the burdens are borne disproportionately by the global South and by the world's most vulnerable communities, including indigenous peoples, racial and ethnic minorities, and the poor. Some scholars have described the ecological segregation of the world's population along economic and racial lines as "eco-apartheid" (emphasis added, footnotes omitted). For another account of the distributive dimensions of environmental justice in relationships between nation-states, see Peter Newell, 'Race, Class and the Global Politics of Environmental Inequality' (2005) 5(3) Global Environmental Politics 70. 
countries' disproportionate contribution to climate change and other environmental harms and noted 'that the largest share of historical and current global emissions has originated' in the global North.

In this context, European countries, being the core of the global North, have contributed extraordinarily to global environmental degradation and climate change. Looking at the historical roots of global distributive environmental injustice, Europe's role becomes even more prominent and appears inseparable from its colonial history:

When European nations conquered America, they laid the groundwork for contemporary disparities in wealth and well-being. [...] Having prospered on the basis of resources extracted from its colonial possessions, the global North continues to exploit the global South at prices that do not reflect social and environmental externalities. In addition, the global North industrialised rapidly and cheaply by using more than its fair share of the global commons, and its per capita ecological footprint continues to dwarf that of the global South. ${ }^{23}$

The criterion often used for visualising the responsibility for global environmental harms are greenhouse gas emissions. Twenty-eight (currently) EU Member States occupy the top end of all lists of global polluters, contemporarily and historically (controlled for size), outranked only by the USA and more recently China. ${ }^{24}$ In addition, European countries have suffered from environmental harms disproportionately less than the majority of other countries in the world, especially the developing ones. $^{25}$

${ }^{23}$ Gonzalez (n 22) 80ff: 'The riches of the New World triggered a scramble among European countries for colonies in Asia, Africa, and the Americas. By 1800, Europe controlled 55 per cent of the global land mass. By 1914, 84.4 per cent of the planet's territory was under the effective control of Europe and the US [...]' (footnotes omitted).

24 I have consulted a number of databases, such as CAIT Climate Data Explorer, World Resources Institute (2015) available at <http://cait.wri.org> accessed 28 October 2019, measuring 'Cumulative Total $\mathrm{CO}_{2}$ Emissions Excluding Land-Use Change and Forestry from 1850 to 2014 (MtCO2)' and listing: 1. United States (374583.6723); 2. European Union (EU28) (333639.1094); 3. China (168761.7539); CO2 Emissions, Global Carbon Atlas (Updated with 2017 figures) available at <www.globalcarbonatlas.org/en/CO2-emissions> accessed 28 October 2019, showing the EU28 being second only to the USA (in MtCO2) in 1960 and 1990, and third (behind China and the USA) in 2017; Global Historical Emissions, Climate Watch, available at <www.climatewatchdata.org/ghg-emissions> accessed 28 October 2019, measuring 'all sectors, all GHG, unit: MtCO2e (gigatons)', and showing: (in 1990) 1. USA: 5550.04; 2. EU (28): 4949.77; 3. China: 2833.49; (in 2014) 1. China: 11600.63; 2. USA: 6319.02; 3. EU (28): 3624.82.

25 This led some authors to propose that the developed (industrialised) countries' contribution to climate change was a moral wrong that required reparations to vulnerable populations in the developing and the least developed countries. See Maxine Burkett, 'Climate Reparations' (2009) 10(2) Melbourne Journal of International Law 509; see also Michael B Gerrard, 'What Does Environmental Justice Mean in an Era of Global Climate Change?' 
The North-South gap is, moreover, present in procedural and corrective dimensions of global environmental injustice. Developed countries, in many aspects led by the EU and its most powerful Member States, have much greater political voice in international decision-making (not only in environmental matters). ${ }^{26}$ At the same time, their responsibility for environmental harms has been shielded by inefficiencies in the legal enforcement of international environmental treaties and in the absence of redress mechanisms. ${ }^{27}$

Second, one might look into environmental injustice at the level of individual EU Member States. Robust research on this has started to emerge only recently. Perhaps surprisingly, Europe lags behind the US in acknowledging and addressing its environmental inequalities. ${ }^{28}$ There are certain obstacles, arguably unknown to American researchers, to identifying environmental injustices in different dimensions in the European nation-states, such as the lack of spatial analysis and statistics or unreliable socio-economic data. ${ }^{29}$

(2013) 19(2) Journal of Environmental and Sustainability Law 278 (discussing environmental justice challenges and implications for climate change mitigation and adaptation). A separate question, raised by one reviewer, that I nevertheless do not take up in this paper, is how addressing environmental injustice at the global level helps address environmental injustice in Europe (discussed below). There may be a flip side to the same question: how addressing environmental injustice in Europe helps address environmental injustice at the global level. This essentially asks for an assessment of the relationship between, and the appropriate order of, the two courses of action, ie internal (intra-EU) and external (worldwide) actions. Although interesting, these questions are not my primary focus here and would in any event merit careful, individual treatment.

26 Gonzalez (n 22) 79: 'In addition to this distributive injustice, North-South relations are also plagued by procedural inequities. The North dominates decision-making in the International Monetary Fund (IMF), the World Bank, the World Trade Organization (WTO) and multilateral environmental treaty fora as a consequence of its greater economic and political clout. While the South can present alternative points of view, the preferences of the powerful generally dictate the substantive outcomes' (emphasis added).

27 ibid: 'Corrective injustice is evident in the plight of small island states whose very existence is threatened by climate change, but who possess no legal mechanism to obtain compensation or cessation of the harmful conduct. In addition, North-South environmental conflicts reflect broader social injustice because they are inextricably intertwined with colonial and postcolonial economic policies that impoverished the global South and facilitated the North's appropriation of its natural resources' (footnotes omitted).

28 Laurent (n 13) 1849: 'Europe, as much as the US, is confronted with the challenge of environmental justice (European social policies cannot ignore anymore health, socio-economic and well-being impacts resulting from poorer environmental conditions faced by their most vulnerable citizens). The European particularism here is only that European Union member states are generally lagging behind and must catch up. This is all the more surprising [given] that Europeans and Americans do differ in their attention to redressing inequalities, with Europeans supposedly keener on correcting them than Americans' (emphasis added).

29 Most notably, in France, minority and race are not constitutionally recognised as categories, nor are they recorded in census or socio-demographic data. See Lucie Laurian, 'Environmental Injustice in France' (2008) 51(1) Journal of Environmental Planning and 
Still, there are clear cases of both environmental classism and racism, where minority communities are found to suffer disproportionally from environmental harms: for instance, in the UK, ${ }^{30}$ France, ${ }^{31}$ Germany, ${ }^{32}$ Italy, ${ }^{33}$ or the countries of Central and Eastern Europe. ${ }^{34}$ With the greater availability of empirical data and the increase in scholarly interest, these and similar cases of environmental injustice in Europe will become even more apparent, especially given the suspected patterns of ethnic and socio-economic segregation in big European cities like Brussels, Antwerp, Amsterdam, Rotterdam, Marseille or Paris. ${ }^{35}$ For now, by

Management 59. See also Hilary Silver and Lauren Danielowski, 'Fighting Housing Discrimination in Europe' (2019) Housing Policy Debate, Forthcoming Special Issue: Fair Housing Act: 50th Anniversary: '[T]he extent of racial or ethnic segregation is often difficult to gauge because not all [European] countries collect statistics on small areas or on race or religion. For example, the French Constitution's prohibition on discrimination based on race has led the Constitutional Court to systematically object to any official collection of information on racial/ethnic identity. In 2018, the National Assembly even voted to remove the word "race" from Article 1 of France's constitution. [...] European governments consider the state's collection of data on race and ethnicity, as in the United States, to be overly intrusive, especially after the Nazi regime's disastrous use of such data'.

30 UK Government, 'UK notification to the European Commission to extend the compliance deadline for meeting $\mathrm{PM}_{10}$ limit values in ambient air to 2011 - Racial Equality Impact Assessment (England)' (August 2009) (identifying the disproportionate impact of air pollution, measured as exposure to concentrations of $\mathrm{PM}_{10}$, on ethnic and racial groups, especially on those identifying as Black or Black-British African).

31 Laurian's research (n 29) demonstrates that 'towns with high proportions of immigrants tend to host more hazardous sites, even controlling for population size, income, [or] degree of industrialization of the town and region' 55. See also Jean-Francois Viel and others, 'Environmental Justice in a French Industrial Region: Are Polluting Industrial Facilities Equally Distributed?' (2011) 17 Health \& Place 257.

32 Tamara Steger (ed), Making the Case for Environmental Justice in Central and Eastern Europe (CEU Center for Environmental Policy and Law, The Health and Environment Alliance, The Coalition for Environmental Justice 2007) 15: 'In Germany, immigrants and less economically viable communities seem to bear the brunt of environmental injustices. Turkish immigrants, for example, work in unsafe conditions and subsequently live near highly polluting factories'.

33 Marco Martuzzi, Francesco Mitis and Francesco Forastiere, 'Inequalities, Inequities, Environmental Justice in Waste Management and Health' 20(1) European Journal of Public Health 21-22: 'Available data provide consistent indications that waste facilities are often disproportionally more located in areas with more deprived residents, or [...] ethnical minorities. This applies to waste incinerators, landfills, hazardous waste sites, legal and illegal. [...] A direct relationship was found between social class and residence near waste facilities in Italy and UK'.

34 Csaba Varga, István Kiss and István Ember, 'The Lack of Environmental Justice in Central and Eastern Europe' (2002) 110(11) Environmental Health Perspectives A662-A663: 'In some countries in Central and Eastern Europe, environmentally hazardous sites and activities are also disproportionally located, with high concentrations in the areas and communities of ethnic or national minorities.'

35 Sako Musterd, 'Social and Ethnic Segregation in Europe: Levels, Causes, and Effects' (2005) 27(3) Journal of Urban Affairs 331 (comparing levels of ethnic and socio-economic segregation in American and European cities and noting that analyses in Europe are constrained by the lack of systematic data); John Iceland, Residential Segregation: A Transat- 
far the most horrific examples of environmental injustice have been recorded in the case of Roma people (especially Romani communities in Central and Eastern Europe), which further proves the ugly truth that this (over-)marginalised ethnic minority is the epitome of the European 'abject other'. ${ }^{36}$

Third, and finally, one might look into possible environmental injustice not externally (globally) or internally (within EU countries), but at the regional, intermediate level, ie between different EU Member States. This is the approach that I adopt here and elaborate in the following sections. The background is as follows: a structural divide within the EU that recently came into focus is between the 'old' Member States of Western and Northern Europe and the 'new' Member States of Central and (South-) Eastern Europe that joined the Union in three enlargement waves during the 2000s and the 2010s. This 'invisible' divide has been conceptualised as the 'centre' (or 'core') v the 'periphery'. ${ }^{37}$ Damjan Kukovec suggests that this divide and the related power dynamics are inherent in the legal and institutional structure of the EU. ${ }^{38} \mathrm{He}$ and other European critical scholars have recently identified legal, socio-economic and policy out-

lantic Analysis (Migration Policy Institute - Transatlantic Council on Migration, September 2014) (arguing that in many European countries residential segregation is a relatively recent immigration-related phenomenon, with different roots from - but similar effects to - residential segregation in the US). Also, Silver and Danielowski (n 29) remarked that '[i]n Europe, the growth in ethnic populations, the mass arrival of refugees, urban riots and terrorist incidents in central cities, and the anti-immigrant rhetoric of far-right parties all contribute to public fears of ghettoization'.

36 See Steger (n 32) (providing ground-breaking research on environmental justice in Central and Eastern Europe and the Balkans, and documenting cases of environmental injustices and the Roma community's exposure to pollution, flooding, denied benefits in access to water, waste management, sewerage, and natural resources); Krista Harper, Tamara Steger and Richard Filcak, 'Environmental Justice and Roma Communities in Central and Eastern Europe' (2009) 19 Environmental Policy and Governance 252: '[I]n certain locations, members of ethnic minorities, communities of lower socioeconomic status and the least educated disproportionately (1) suffer from exposure to environmental hazards due to their proximity to hazardous waste sites, incinerators, factories, abandoned industrial facilities and other sources of pollution and/or (2) are denied environmental benefits such as potable water, sewage treatment facilities, sanitation and access to natural resources and/ or (3) witness the conceptualization of their living space as "beyond the pale" areas where environmentally controversial practices are concentrated'; Attila Antal, 'Climate and Social Justice in Eastern and Southern Europe: The Social Nature of Climate Change' (2018) Working Paper 1, INOGOV Network: Innovations in Climate Governance 3 (discussing challenges related to environmental and climate injustice regarding Roma communities in the Eastern and Southern European regions).

37 Damjan Kukovec, 'Law and the Periphery' (2015) 21(3) European Law Journal 408: '[T]he position of the EU's periphery is not reflected in the existing EU legal discourse. First, the way the EU is structured and the way issues are framed for discussion makes it difficult to notice and address distributional consequences of the EU legal structure between the centre and the periphery. Second, many of the periphery's aspirations and claims for protection against harm are foreclosed from operating powerfully in the Union'.

38 ibid, 407. 
comes unevenly distributed among different Member States due to the structural bias of the EU internal market in favour of citizens, workers, goods, services, companies and industries from the EU's centre, which creates hierarchies between 'insiders' and 'outsiders' in relation to EU integration. ${ }^{39}$ Therefore, the EU's institutional setup and internal market tend to operate not to level-down economic inequalities between the EU centre and periphery, but to amplify them and make the rich richer and the poor poorer. ${ }^{40}$

Echoing US critical legal scholars, this group of authors claims that EU law serves the purposes of the powerful centre, often masking the centre's particular interests as the EU's 'universal' interest. ${ }^{41}$ Recent comprehensive studies confirm that the impact of the EU internal market, a flagship EU integration project 'for everyone' and arguably its raison d'être, on real incomes (that is, on the GDP per capita and per year) is the strongest in the 'core' EU countries and regions who thus reap much more benefit than the EU's periphery (Member States in Southern and Eastern Europe). ${ }^{42}$ So, Mion and Ponattu conclude, these uneven 'gains from the [internal market] may further reinforce pre-existing regional differences, this way adding to the core-periphery pattern and inequality more generally'. ${ }^{43}$

39 Damjan Kukovec, 'Economic Law, Inequality and Hidden Hierarchies on the EU Internal Market' (2016) 38(1) Michigan Journal of International Law 1; Tamara Perišin, 'Transformation or Reconstitution of National Regulatory Policies at the EU Level: Insiders and Outsiders under Free Movement Rules' in Tamara Perišin and Siniša Rodin (eds), The Transformation or Reconstitution of Europe. The Critical Legal Studies Perspective on the Role of the Courts in the European Union (Hart Publishing 2018) 153; Marija Bartl, 'Internal Market Rationality, Private Law and the Direction of the Union: Resuscitating the Market as the Object of the Political' (2015) 21(5) European Law Journal 572.

40 Kukovec (n 37) 410.

41 ibid, 423.

42 Giordano Mion and Dominic Ponattu, Estimating Economic Benefits of the Single Market for European Countries and Regions: Policy Paper (Bertelsmann Stiftung 2019) 1, available at <www.bertelsmann-stiftung.de/fileadmin/files/BSt/Publikationen/GrauePublikationen/EZ_Study_SingleMarket.pdf> accessed 28 October 2019, who note that 'observed trends are largely consistent with the widely discussed "core-periphery" pattern across EU' (6); although 'some Eastern European countries see strong relative welfare gains [from the EU internal market], while monetary gains in absolute terms are low [...] other countries in the periphery [...] see both low welfare gains in absolute and relative terms, suggesting that, at least partly, gains from the [internal market] follow a core-periphery logic: Countries in the southern and eastern European periphery do not appear to gain in the same way that countries in the core do' (11).

43 ibid, 23. See, in particular, Figure 4 showing per capita welfare gains from the internal market that perfectly follows the distribution of Member States into 'centre' and 'periphery' categories, and almost perfectly the distribution into 'semi-periphery' and 'periphery' (21). 
At the top of the hierarchy there would usually be the same Member States from the EU centre that include Germany, France, the UK, Belgium, the Netherlands, Luxembourg, Austria, Denmark, Sweden, and Finland, ${ }^{44}$ while the bottom is occupied by the EU's peripheral Member States, such as Poland, Hungary, the Czech Republic, Slovakia, Bulgaria, Romania, Cyprus, Malta, Latvia, Lithuania, Estonia, Slovenia, and Croatia. ${ }^{45}$ Notably, almost the entire EU periphery is made up of post-communist countries that underwent democratic and economic transition in the 1990s that caused the even greater impoverishment of their most vulnerable communities and regions. ${ }^{46}$

44 Kukovec (n 37) 408-409 explains that Member States of the centre have 'much higher gross domestic product (GDP) per capita than the regions of the periphery; they invest more money in research and development and have the best universities; they have more capital and more ingoing and outgoing foreign direct investment (FDI). Their actors, products and services have more prestige. Internationally recognised brands come from the centre, which gives the companies owning them a significant power on the market. [...] Generally, companies of the centre find themselves higher in European and global production chains. The centre exports final products and is the seat of powerful corporations and law firms' (footnotes omitted).

45 ibid, 409: 'The periphery has much weaker industry and a less efficient agricultural sector. It has no (or very few) brands known beyond its borders. Non-branded companies typically earn lower margins and are constantly at risk of being undercut by cheaper rivals. Some of the few famous brands of Eastern Europe have in fact been bought by established companies of the centre. Regions of the periphery have a lower GDP per capita, and the actors, products and services from the periphery have much less prestige. They often produce semi-final products or final products for a brand of the centre. Generally, companies of the periphery find themselves lower in European and global production chains. The wages are lower than in the centre, and often (with the exception of the European south) the life expectancy is lower' (footnotes omitted). Kukovec further notes that Member States like Spain, Portugal, Italy, Greece or Ireland could be considered in some respects as 'centre' and in others as 'periphery', thus designating them as 'semi-periphery'. Here, in response to a reviewer's comment, it should also be noted that the choice of individual countries as the relevant units of analysis and comparison seems inevitable. Granted, there may be some variables (like consumption, instead of industrial emissions, as a measure of contribution to environmental harm) that would privilege, for example, regions rather than countries as objects of inquiry. However, given that sovereign (nation-)states, conceptualised as aggregated subjects with homogenous interests, are still taken as the primary actors in international relations and international (environmental) law, this paper follows the same approach, acknowledging that in some respects it might appear overgeneralised or simplified. In addition, the progress of EU economic and political integration, in my view, still does not render obsolete the concept of individual Member States as units of scholarly analysis.

46 Harper, Steger and Filcak (n 36) 255: The transition to a free market economy in [Central and Eastern European] countries has led to further impoverishment of regions, groups and individuals that are disadvantaged by new market conditions' (references omitted). And, as documented by research such as that by Mion and Ponattu (n 42), the integration of the 'new' Member States' economies in the EU internal market has further contributed to the widening of the gap between the EU's 'haves' and 'have nots' in relative terms, as well as to growing inequalities (economic and others) within the peripheral Member States themselves, as briefly mentioned above (see the text accompanied by footnotes 34 and 36). 


\section{Environmental (in)justice and the EU centre and periphery}

Is it useful to think about environmental (in)justice in the EU through the centre-periphery divide? ${ }^{47}$ I believe there are strong indicators that support such an approach. What follows are some arguments that show that the EU periphery has been much less responsible for environmental harms in Europe (and in the world) yet bears greater environmental burdens and has less access to environmental decision-making than the EU centre. I divide them into categories tracking different dimensions of environmental justice that were introduced at the beginning: distributive on the one hand, and procedural and corrective on the other.

\subsection{Distributive injustice}

Does distributive environmental injustice between the EU's centre and periphery exist? Here I want to look into the unequal distribution of environmental resources, responsibility and burdens between the Member States, and the uneven political clout in the EU institutional framework. (Note that it could also be possible to treat the latter as an issue of procedural (in)justice; however, I take the distribution of political power and institutional resources in the EU as a prima facie issue of distributive (in)justice. This arguably makes the assessment of this element of distributive environmental injustice in the EU more conventional, due to an idiosyncratic use of the notion of procedural and corrective environmental justice in the context of the Aarhus Convention, as will be elaborated in the next part.)

First, the emissions record and ecological footprint. Member States of the EU centre have a significantly greater historical emissions record than the peripheral ones. ${ }^{48}$ This holds for both absolute emissions and

47 See Pamela Ballinger, 'Whatever Happened to Eastern Europe? Revisiting Europe's Eastern Peripheries' (2017) 31(1) East European Politics and Societies and Cultures 44, for the argument (albeit in a different context) that the concept of centre-periphery power dynamics 'possess[es] continuing political and scholarly relevance' (46) and 'offers a particularly powerful lens through which to consider the recombinations and intersections of old distinctions - North versus South, East versus West - shaping the landscape of contemporary Europe' 61.

48 The World Bank, Data: $\mathrm{CO}_{2}$ emissions (kt) (Carbon Dioxide Information Analysis Centre, Environmental Sciences Division, Oak Ridge National Laboratory, Tennessee, US) available at <https://data.worldbank.org/> accessed 29 October 2019. This dataset measures $\mathrm{CO}_{2}$ emissions per kiloton from 1960. Similar data are shown in Climate Watch (n 24), measuring 'all sectors, all GHG, unit: MtCO2e (gigatons)', with 1990 as the base year; and in Global Carbon Atlas (n 24), with the earliest record from 1960, measured in MtCO2, and showing Germany, the UK, Italy, France, and Poland in the top 10 global polluters. By 2017, only Germany has remained in the top 10. Finally, CAIT Climate Data Explorer (n 24), showing 'Cumulative Total $\mathrm{CO}_{2}$ Emissions Excluding Land-Use Change and Forestry from 1850 to 2014 (MtCO2)', lists the EU Member States in the following order (periphery italicised): Ger- 
per capita emissions (albeit less stark for the latter), ${ }^{49}$ with Poland being the only outlier among the peripheral Member States. ${ }^{50}$ Similar indicators are present for the ecological footprint, where absolute and per capita values show the greater contribution of the EU centre to environmental degradation. ${ }^{51}$

That historical emissions are undeniably much greater in the EU centre is largely the result of the $19^{\text {th }}$ century coal-driven industrial revolution. Currently, coal power plants account for around 18\% of EU greenhouse gas emissions. ${ }^{52}$ Two of the greatest coal polluters among EU countries are Germany (first) and Poland (second), accounting for 55\% of the EU's total coal generation. ${ }^{53}$ However, it may be argued that in the case of Western and Eastern Europe - more specifically, taking into account their level of economic development and historical polluting record -contemporary coal generation represents so-called 'luxury' and 'necessity' emissions, respectively.

many 86024.7389; United Kingdom 71280.9583; France 34596.7042; Poland 24993.2304; Italy 21864.8292; Spain 12794.2567; Belgium 11548.7171; Czech Republic 11228.059; Netherlands 10285.1113; Romania 7750.9491; Austria 4996.3337; Sweden 4629.0875; Hungary 4554.9729; Denmark 3862.078; Bulgaria 3499.4903; Greece 3470.0734; Slovakia 3312.872; Finland 2878.9714; Portugal 2224.3081; Ireland 1950.781; Estonia 1317.9452; Lithuania 1148.5176; Croatia 934.0579; Slovenia 725.9222; Luxembourg 721.9622; Latvia 708.8152; Cyprus 243.2793; Malta 92.0882.

49 Compare $\mathrm{CO}_{2}$ emissions per kiloton for Central Europe and the Baltics (Bulgaria, Croatia, Czech Republic, Estonia, Hungary, Latvia, Lithuania, Poland, Romania, Slovak Republic, Slovenia): 1960 - 466,533 (low); 1979 - 1,168,855; 1987 - 1,241,032 (peak); 2014 - 636,386; for the European Union (all current 28 countries): 1960 - 2,359,595 (low); 1979 - 4,647,644 (peak); 1987 - 4,258,990; 2014 - 3,241,844. Also, $\mathrm{CO}_{2}$ emissions (metric tons per capita) for Central Europe and the Baltics: 1960 - 5.1; 1980 - 11.3 (peak); 1992 - 7.9; 2014 - 6.1; for the European Union: 1960 - 5.8; 1979 - 10.0 (peak); 1992 - 8.3; 2014 6.4. Luxembourg has the biggest historical (and contemporary) per capita emissions in the entire EU. Although per capita emissions observed in per annum figures might suggest to some that no significant differences exist between the EU centre and periphery, it should be noted that these differences have remained constant for decades of measurements, most probably stretching beyond the base year (1960) due to the differentiated industrial development in the Europe's West and East.

50 In 2014, the EU top 6 in $\mathrm{CO}_{2}$ emissions per kiloton were: Germany 719,883; United Kingdom 419,820; Italy 320,411; France 303,276; Poland 285,740; Spain 233,977.

51 Global Footprint Network, available at <http://data.footprintnetwork.org $>$ accessed 29 October 2019. The Ecological Footprint is a measure combining the use of built-up land, carbon, cropland, fishing grounds, forest products, grazing land, and expressed as 'gha global hectare'. The 1993 (the earliest) and 2014 (the latest) measures for 'gha - global hectare per person' showed Luxembourg, Denmark and Belgium on the top. The 1993 and 2014 measures for 'gha - global hectare total' showed Germany, the UK and France on the top.

52 Europe Beyond Coal, Database of Europe's Coal Plants, available at <https://beyond-coal.eu/data/> accessed 29 October 2019.

53 Silvio Marcacci, 'Uneconomic Coal Could Be Squeezed Out of European Union Power Markets by 2030' (Forbes, 11 June 2018), available at <www.forbes.com/sites/energyinnovation/2018/06/11/uneconomic-coal-could-be-squeezed-out-of-european-union-powermarkets-by-2030/\#4937824c4179> accessed 29 October 2019. 
What is also notable here is that all Member States of the EU centre have either closed their coal plants or announced their shutdown, ${ }^{54}$ whereas no peripheral EU Member State (with currently operating coal plants) has announced a phase out. ${ }^{55}$ On the contrary, in some countries (mainly Poland, Greece and other countries in the South-Eastern Europe) new coal plants are being constructed or planned. ${ }^{56}$ This indicates that a high-polluting coal and lignite ${ }^{57}$ industry has moved from the centre (Western Europe) to the periphery (Eastern Europe); not literally, of course (as in one plant shutting down production in the West and reopening in the East, although some other Western producers, for instance car companies, might have indeed moved some pollution-intensive segments of their production process to Eastern Europe). Still, despite everything, the centre nowadays remains a greater polluter than the periphery, measured by $\mathrm{CO}_{2}$ emission from coal and $\mathrm{MW}$ operating capacity, ${ }^{58}$ while the periphery arguably suffers more overall. ${ }^{59}$ More generally, coal generation harms the EU's effort to tackle climate change and reduce its emissions reported in the framework of the 2015 Paris Agreement. ${ }^{60}$

54 ibid. For instance, France by 2023, Italy and the UK by 2025, and the Netherlands by 2030 (accounting for $22 \%$ of total EU generation), while Germany is expected to set an end date in 2019.

55 Climate Analytics, A Stress Test for Coal in Europe under the Paris Agreement. Scientific Goalposts for a Coordinated Phase-Out and Divestment (February 2017).

56 The Economist Intelligence Unit, 'Europe Energy: Coal Use Falls again in Europe in 2017' The Economist (London, 28 February 2018) available at <www.eiu.com/industry/ article/1846475768/coal-use-falls-again-in-europe-in-2017/2018-02-28> accessed 29 October 2019. ('In Eastern Europe, however, dependence on coal remains high: this region accounts for five of the six EU member states where coal provides more than $30 \%$ of power generation. This is because of sizeable coal deposits (including lignite) in several parts of Eastern Europe, which support the production of affordable electricity, reduce the need for energy imports, and maintain employment in the mining sector. Furthermore, renewables usage in this region has been stunted by lack of policy support and the high costs of financing').

57 ibid: 'A large share of Europe's coal generation (46\%) is also sourced from carbon-intensive lignite. Germany, Poland, Czech Republic, Bulgaria and Romania account for almost all of the EU's lignite use, which is also used in some non-EU states in the Western Balkans. Easing the region's dependence on lignite would contribute significantly to reducing Europe's power sector emissions. However, the EU would need to support the region's more vulnerable economies as they made this transition [to renewables], to minimise the social and economic costs and prevent a policy backlash'.

58 Europe Beyond Coal (n 52).

59 Climate Analytics (n 55) 3: 'Coal power stations in five countries contributed more than a quarter to total national GHG emissions: $28 \%$ in Germany, 33\% in Poland and in Czech Republic, $34 \%$ in Greece and as much as $44 \%$ in Bulgaria.'

60 ibid, 1. 
Second, waste generation. In general, the production and export of waste in the EU has grown significantly during recent decades. ${ }^{61}$ Current data show that Member States of the EU centre are the primary waste producers in Europe, with a few outliers. ${ }^{62}$ The same countries are the EU's greatest generators of hazardous waste, too: ${ }^{63}$ entities that produce hazardous waste are predominantly located in the Member States of the EU centre. ${ }^{64}$ Moreover, the production of hazardous waste is increasing in the EU centre, while decreasing in its periphery. ${ }^{65}$

There are also some issues with illegal waste shipping from the EU centre to the periphery, where Western European companies are dumping waste (so-called 'waste tourism') in the EU's East. ${ }^{66}$ This seems to be

61 European Environment Agency, Movements of Waste Across the EU's Internal and External Borders, EEA Report No 7/2012 (EU Office for Official Publications 2012) 5: '[T]he growth in cross-border waste trade during recent years has been remarkable. Exports of waste iron and steel, and copper, aluminium and nickel from Member States doubled between 1999 and 2011, while waste precious metal exports increased by a factor of three and waste plastics by a factor of five. Similarly, exports of hazardous waste more than doubled in the period 2000-2009'.

62 Eurostat, Waste Statistics, available at <https://ec.europa.eu/eurostat/statistics-explained/index.php/Waste_statistics> accessed 29 October 2019. ('As might be expected, the overall amount of waste generated is related to some extent to the population and economic size of a country. [T]he smallest EU Member States generally reported the lowest levels of waste generation and the larger ones the highest. Nevertheless, relatively high quantities of waste were generated in Bulgaria and Romania [mostly from mining and quarrying] and a relatively low quantity in Italy'.)

63 Mahelet G Fikru, 'Trans-boundary Movement of Hazardous Waste: Evidence from a New Micro Data in the European Union' (2012) 4(1) Review of European Studies 3. Note also that ' $96 \%$ of the export stays within Europe and rarely goes to developing countries. [...] The large share of trade in hazardous waste among EU Member States is mainly due to Regulation (EC) No 1013/2006 (also known as Waste Shipment Regulation) which prohibits the export of hazardous wastes to non-OECD countries' 3-5 (footnotes omitted).

64 More than two-thirds of the EU's total come from Spain, Italy, the UK, France, and Germany. From the EU periphery, hazardous waste producers come mostly from Poland, the Czech Republic and Hungary. See Fikru (n 63) 10.

65 European Environment Agency (n 61) 11: 'There is clear evidence that EU output of hazardous waste is increasing. [...] [H]owever, the aggregate growth masks contrasting trends within the EU. Whereas EU-15 output of hazardous waste grew substantially $(70 \%)$ in the period 1997-2009, EU-12 production actually declined by 36\%. [...] Among EU Member States, Germany generated the most hazardous waste in 2009 with 17 million tonnes (Mt). It was followed by Italy ( $11 \mathrm{Mt})$, France (11 Mt) and Estonia (7 Mt). Estonia's large output of hazardous waste primarily results from oil shale mining (95\%)'.

66 European Environment Agency, Waste Without Borders in the EU? Transboundary Shipments of Waste. EEA Report No 1/2009 (EC Office for Official Publications 2009) 4 and 11-12. However, these accounts are hard to verify due to a lack of information and enforcement. See also Martuzzi, Mitis and Forastiere (n 33) 23: '[B]esides differential levels of exposure to waste-related contaminants by socio-economic levels at local or national level, inequalities in exposure might take place at the international level, through the transfer of related hazards from one country to another. In fact, illegal shipment and disposal of hazardous waste is of growing relevance in some countries of central and eastern Europe'. 
a continuation of unjust practices that started in recent decades, before the EU's eastern enlargement:

richer countries [are using] poor countries as a 'sink' for pollution and waste. [...] A similar dynamic has emerged within Europe, where companies in the more prosperous regions of the European Union are outsourcing waste disposal to municipalities in poorer countries in Central and Eastern Europe [CEE]. This process began in the early 1990s, when the change of political systems facilitated trade between east and west, and when one German firm infamously exported hazardous waste to Albania in barrels labeled 'humanitarian aid'. The east-west trade in waste has accelerated with CEE countries' accession into the European Union. ${ }^{67}$

On a global level, there are concerns about the shipments of waste from the EU to developing countries (especially in Western Africa), ${ }^{68}$ again with possibly the greater involvement of the EU centre as the predominant waste producer.

Third, energy poverty and living conditions, ${ }^{69}$ both inextricably related to the state of the environment. Most of the energy poverty indicators show the presence of the centre-periphery divide in the EU. ${ }^{70}$ For instance, data on arrears on utility bills, ${ }^{71}$ the inability to keep the home

\footnotetext{
67 Steger (n 32) 16 (footnotes omitted), and further: 'In January 2007, a major Hungarian news outlet reported that dozens of small municipalities and firms in Hungary have made contracts for German firms to dump their waste, in most cases without consulting local residents. Such cases offer a lens on the international and local dimensions of environmental inequalities'.

68 European Environment Agency (n 61) 5: '[Although] hazardous waste exports overwhelmingly stay within the EU, primarily going to neighbouring countries [...] a substantial proportion of non-hazardous waste exports goes to non-EU destinations'. Also, 'E-waste is normally classified as hazardous and it is therefore illegal for EU Member States to export it to non-OECD countries. Despite shortcomings in EU data on e-waste trade, however, there are many indications that a substantial portion of Europe's e-waste is exported to areas such as West Africa and Asia, disguised as used goods (6). [...] Treatment in these countries usually occurs in the informal sector, causing significant environmental pollution and health risks for local populations' (26).

69 Stefan Bouzarovski and Sergio Tirado Herrero, 'The Energy Divide: Integrating Energy Transitions, Regional Inequalities and Poverty Trends in the European Union' (2017) 24(1) European Urban and Regional Studies 69: 'Energy poverty can be understood as the inability of a household to secure a socially and materially necessitated level of energy services in the home'.

70 EU Energy Poverty Observatory, Indicators \& Data, available at <www.energypoverty.eu/ indicators-data> accessed 29 October 2019. These data are summarised in European Energy Network, 'Position Paper on Energy Poverty in the European Union' (January 2019) 6-7.

${ }^{71}$ EU Energy Poverty Observatory (n 70), 'Arrears on utility bills' (\% of population): above EU average (of about 10\% of population) are Greece (above 35\%, the most), Bulgaria, Croatia, Romania, Hungary, Slovenia, Latvia and Cyprus (Poland and Lithuania follow, just below the average).
} 
adequately warm, ${ }^{72}$ poverty risk, ${ }^{73}$ the presence of leak, damp or rot in the dwelling, ${ }^{74}$ or energy expenses ${ }^{75}$ all demonstrate that Member States of the EU periphery (in some instances, semi-peripheral Member States included) are disproportionally affected by problems related to energy poverty. In other words,

[w] hile the [energy poverty] is widespread across Europe, its spatial and social distribution is highly uneven. [...] [T] he classic economic development distinction between the core and periphery also holds true in the case of energy poverty, as the incidence of this phenomenon is significantly higher in Southern and Eastern European EU Member States. ${ }^{76}$

\section{Bouzarovski and Tirado Herrero in their recent study further}

challenge the findings of previous studies by suggesting that the traditional division of EU states into three clusters is increasingly replaced by a relatively well-off 'core' group of countries in Northern and Western Europe, and a heterogeneous 'energy poverty periphery' in the South and East. In the former, domestic energy deprivation is limited to specific demographic and housing groups, while the latter exhibits a more pervasive presence of the problem across a range of social strata. ${ }^{77}$

Moreover, this 'energy poverty' divide is arguably furthered by the EU energy market regulation and clean energy transition strategy. ${ }^{78}$ (Later in the paper, I address in greater detail the link between the EU (envi-

72 ibid, 'Inability to keep home adequately warm' (\% of population): above EU average (of about $10 \%$ ) are Bulgaria (above $40 \%$, the most), Lithuania, Greece, Portugal, Cyprus, Latvia, Romania and Croatia (Hungary, Poland and Spain follow, just below average).

73 ibid, 'Poverty risk' (people at risk of poverty or social exclusion, $\%$ of population): above EU average (of about 23\%) are Bulgaria (around 40\%, the most), Romania, Greece, Lithuania, Italy, Latvia, Cyprus, Spain, Croatia, Hungary, Ireland and Portugal.

74 ibid, 'Presence of leak, damp, rot' (\% of population with leak, damp or rot in their dwelling): above EU average (of around 14\%) are Portugal (with more than 30\%, the most), Hungary, Cyprus, Slovenia, Latvia, Belgium (outlier from the EU centre), Lithuania, Estonia and Greece (with Spain just below the average).

75 ibid, 'Energy expenses, income quintile 1-5' (consumption expenditure for electricity, gas and other fuels as a \% of income for income quintile 1-5): Czech Republic (almost 18\% of population, the most), Slovakia, Greece, Latvia, Bulgaria, Hungary, Croatia, Poland, Slovenia, Lithuania, Germany (outlier, just above $8 \%$ ).

76 Bouzarovski and Tirado Herrero (n 69) 69ff: '[T]he existence of a geographical energy poverty divide in the [EU] provides a starting point for conceptualizing and exploring the relationship between energy transitions - commonly described as wide-ranging processes of socio-technical change - and existing patterns of regional economic inequality'.

77 ibid, 82ff: "[T]he notion of the "energy divide" can be expanded from its original predominantly socially orientated meaning [...] to encapsulate existing inequalities in access to infrastructure services at the scale of cities, regions and countries'.

78 ibid, 83: 'There is also a necessity for acknowledging the price and energy poverty risks posed by wider energy transition processes stemming from the liberalization and privatization of the energy sector and the long-term transition to a low-carbon future'. 
ronmental, energy, market) regulation and environmental injustice and inequalities).

Regarding living conditions, besides a clear centre-periphery divide in energy poverty and income distribution, ${ }^{79}$ there is a similar geographical difference in overcrowded households, ${ }^{80}$ as well as pollution, grime and other environmental issues, ${ }^{81}$ found to be more prevalent in the EU periphery.

Fourth, air quality. Recent data indicate that in many respects the quality of ambient air is notably worse in the peripheral than in the centre EU Member States. ${ }^{82}$ For example, Member States of the periphery have been indicated as predominantly exposed to particulate matter pollution, among them Bulgaria, Greece, and Poland having the worst air quality. ${ }^{83}$ Similarly, concentrations of benzo[a]pyrene and carbon monoxide have been the highest in Central and Eastern European Member States, like Poland, Bulgaria, Slovakia, Slovenia and Croatia. ${ }^{84} \mathrm{High}$ levels of benzene concentrations have likewise been disproportionally pres-

79 Eurostat, Living Conditions in Europe - 2018 edition (EU Publications Office) 9: '[Data reveal] a clear geographical divide, insofar as the highest levels of median disposable income were generally recorded in western and Nordic Member States, although the level of income was also above the EU-28 average in Malta. By contrast, median disposable incomes were generally lower in southern Europe, while the lowest levels of income were recorded in eastern Europe and the Baltic Member States'.

80 ibid, 54: 'Overall, 16.6\% of the Europeans lived in an overcrowded household in 2016. There were considerable differences between European Union (EU) Member States, with overcrowding more prevalent in the southern and eastern Member States'.

81 ibid, 64-65: '[N]oise was the main problem reported in a majority (20 out of 28) of the EU Member States in 2016. It was however more common to find that people in Latvia, Lithuania, Hungary, Malta and Slovenia complained about problems relating to pollution, grime or other environmental issues'.

82 European Environment Agency, Air Quality in Europe - 2018 Report (EU Publications Office 2018). See also European Air Quality Index, available at <http://airindex.eea.europa.eu/> accessed 29 October 2019 (picturing 'the air quality divide', ie a divide in the toxic particulate matter air pollution between the countries of South-Eastern and Eastern Europe and the counties of Western Europe); Zoë Schlanger, 'There's an iron curtain dividing Europe into safe and dangerous places to breathe' (Quartz, 30 January 2018) available at <https://qz.com/1 192348/europe-is-divided-into-safe-and-dangerous-placesto-breathe/> accessed 29 October 2019.

83 The European Environment Agency's report (n 82) measures, among other things, 'PM10 (particulate matter with a diameter of $10 \mu \mathrm{m}$ or less) concentrations in relation to the daily and annual limit value in 2016' $(27,29)$; 'PM2.5 (particulate matter with a diameter of 2.5 $\mu \mathrm{m}$ or less) concentrations in relation to the annual limit value in 2016' (31); 'Average Exposure Indicator in 2016' and exposure concentration obligation (33). See also concentration interpolated maps of PM10 (annual mean, $\mu \mathrm{g} / \mathrm{m} 3$ ), PM2.5 (annual mean, $\mu g / \mathrm{m} 3$ ), NO2 (annual mean, $\mu \mathrm{g} / \mathrm{m} 3$ ), and O3 (SOMO35, $\mathrm{gg} / \mathrm{m} 3$.days) for the year 2015 (58).

84 ibid, 'European air quality standard and reference level for benzo[a]pyrene (BaP)': 'A total of 13 Member States measured concentrations above 1.0 ng/m3 in 2016 (see Figure 7.1). As in previous years, values above $1.0 \mathrm{ng} / \mathrm{m} 3$ are most predominant in central and eastern Europe' (48-50). See also 'Data on concentrations of carbon monoxide (CO) in 2016' (52). 
ent in (semi-)peripheral Member States, especially in Romania, Poland, Latvia, Italy and Greece. ${ }^{85}$

The European Environment Agency's report also shows links between the exposure to particulate matter and premature deaths and years of life lost: although in absolute numbers the estimates show that Member States with the largest populations suffer the most, in relative (per capita) terms there seems to be a gap between the EU centre and periphery, at the expense of the latter. ${ }^{86}$

Fifth, institutional resources. In the EU, decisions are made by the 'legislative triangle', (most often) acting in the so-called 'ordinary legislative procedure': the European Commission initiates draft laws that are deliberated and adopted jointly by the Council of the EU (Council of Ministers) and the European Parliament. Since the European Commission (ideally) represents the interests of the Union and is composed of independent members, distribution of political power between the Member States mostly depends on the institutional setup of the Council (the US analogue would be the Senate) and the Parliament (the US analogue would be the House).

In the Council, every Member State is formally equal: it is represented by a single minister and has a single vote. However, a decision is adopted if it satisfies the 'double majority' requirement: a majority of Member States (55\%) representing a majority of the EU population (65\%). ${ }^{87}$ To satisfy the first criterion, sixteen out of twenty-eight Member States would have to vote in favour of a proposal. This means that peripheral Member States (thirteen of them), if joined in a bloc, can prevent a proposal from being adopted. However, if even the smallest Member State of the EU periphery switched sides, the proposal would pass since Member States of the centre strongly dominate the second criterion (total of the EU population represented). On the flip side, controlling the criterion of

\footnotetext{
85 ibid, 53: 'Concentrations of benzene (C6H6) in 2016'.

86 ibid, 63: 'For PM2.5 [particulate matter with a diameter of $2.5 \mu \mathrm{m}$ or less], the highest numbers of premature deaths and [years of life lost] are estimated for the countries with the largest populations (Germany, Italy, Poland, France and the United Kingdom). However, in relative terms, when considering [years of life lost] per 100,000 inhabitants, the largest impacts are observed in central and eastern European countries where the highest concentrations are also observed, ie Kosovo, Bulgaria, Serbia, the former Yugoslav Republic of Macedonia, and Hungary. The lowest relative impacts are found in the countries at the northern and north-western edges of Europe: Iceland, Norway, Ireland, Sweden and Finland.' See also World Health Organization, World Health Statistics 2017: Monitoring Health for the SDGs, available at <www.who.int/gho/publications/world_health_statistics/2017/ en/> accessed 29 October 2019 (documenting the highest (i) levels of air contamination in the cities and (ii) death rates attributed to air pollution in Europe in the countries of South-Eastern and Eastern Europe).

87 Council of the EU, Voting System - Voting Calculator, available at <www.consilium.europa.eu/en/council-eu/voting-system/voting-calculator/> accessed 29 October 2019.
} 
the total EU population enables a couple of core Member States to veto any proposal. For instance, if all eighteen peripheral and semi-peripheral Member States agreed on a proposal, they would still fall short of satisfying the population criterion since they cover only slightly over $45 \%$ of the total EU population. The voting system in the Council thus allows three of the most populous core Member States (Germany, France and the UK) plus any other fourth (a total of four votes are needed to form a blocking minority) to block any proposal.

In the EU Parliament, Member States are represented by directly elected national representatives. The apportionment of seats favours the smaller Member States (including those of the EU periphery) whose populations are thus overrepresented in the Parliament. However, the internal working procedures strongly favour the Member States of the EU centre, who then effectively control agenda setting. In many parliamentary bodies through which a lot of work is done, Member States of the EU periphery are underrepresented. ${ }^{88}$ The key posts in the Parliament that have a strong influence over parliamentary proceedings - the vice-presidents of the Parliament, the presidents of the parliamentary committees, the vice-presidents of the committees, the committee coordinators - are predominantly held by representatives from the EU centre ${ }^{89}$ For illustration, the distribution of the posts of committee coordinators remarkably privileges the EU centre:

[O]n important dossiers, the 'old' member countries have dominant positions, especially in terms of committee coordinators. [...] [T]hey are the 'traffic controllers' of political groups, they distribute the roles of their deputies within the committees, in particular to steer the parliamentary reports and negotiations on amendments. 33 of 189 coordinators of this legislature are German, 21 French, 18 Italian, 16 British and 13 Spanish or Dutch. ${ }^{90}$

Moreover, due to the voter turnout in European elections, the Parliament is less representative of voters from the EU periphery. ${ }^{91}$

\footnotetext{
88 Eric Maurice and others, 'Bilan de la 8ème législature du Parlement européen [Review of the 8th Legislature of the European Parliament]' (2019) Fondation Robert Schuman Policy Paper, Question d'Europe, No. 512, available at <www.robert-schuman.eu/fr/doc/questions-d-europe/qe-512-fr.pdf> accessed 29 October 2019.

89 ibid, 8: From a total of 440 top positions in the Parliament, Germany holds 74, France 44, and Italy 42. At the bottom end are Latvia with 1, Cyprus 1, Slovenia 2, Lithuania 3 , Estonia 3, Croatia 3, Ireland 4, Luxembourg 4, Slovakia 6, and Greece 6.

90 Georgi Gotev, 'Report: Some Countries Clearly Under-represented in Outgoing European Parliament' (EURACTIV, 24 April 2019) available at <www.euractiv.com/section/eu-elections-2019/news/report-some-countries-clearly-under-represented-in-outgoing-european-parliament/> accessed 29 October 2019.

${ }_{91}$ The lowest turnout for the elections in 2014 was in Member States of the EU periphery: Slovakia 13\%, Czech Republic 18\%, Poland 23\%, Slovenia 24\%, Croatia 25\%, Hungary
} 
Going back to the issue of environmental justice: the structural inequalities reviewed in this section - in environmental responsibility and burdens, and in institutional power - suggest the existence of a stark divide between the EU centre and periphery in the distributive dimension. Of course, this is not an exhaustive list of examples of the unequal distribution of environmental and political 'goods' and 'bads' between the Member States - many others, most certainly, could be encountered - but rather the most indicative instances of the existing injustices, as usually observed in the relevant literature. I reflect later in the paper on the possible ways to address this distributive environmental injustice among the EU countries.

\subsection{Procedural and corrective injustice}

As hinted in the very first paragraph of the paper, the procedural and corrective dimensions of environmental justice are what is usually understood as 'environmental justice' in the EU. Of particular importance in this context is the Aarhus Convention. ${ }^{92}$ This international treaty establishes the so-called 'three pillars of environmental democracy': the right of access to environmental information, the right of public participation in environmental decision-making, and the right of access to justice in environmental matters. These three rights are seen as interdependent and mutually reinforcing: access to information is thus a necessary prerequisite for meaningful participation, while access to justice is a means to enforce the other two rights.

The Aarhus Convention in the EU is usually celebrated as a success story. The EU institutions adopted a range of regulations and directives to implement the Convention's provisions, applicable to both the Member States and the EU itself. The Court of Justice of the EU (CJEU) fol-

29\%, Latvia 30\%, Romania 32\%. The EU average was $42 \%$. See European Parliament, Voters Turnout - 2014 European Elections (Results by Country), available at <www.europarl.europa.eu/about-parliament/en/in-the-past/previous-elections> accessed 29 October 2019. A similar pattern emerged in the 2004 and 2009 elections. Although, in general, voter turnout has been in decline for national parliamentary elections across Europe, the decline for European elections has been even greater. See Perišin and Koplewicz (n 21) XX-XXI, who conclude that "while we see a general move away from engagement with governments, at the EU level this is more severe'. The latest 2019 European elections saw a rise in overall voter turnout (51\% at the EU level). However, per Member State, there is a lower but still identifiable centre-periphery gap, with the lowest turnout recorded in Slovakia (22\%), Slovenia (28\%), Czech Republic (28\%), Croatia (29\%), Bulgaria (30\%), Portugal (31\%) and Latvia (33\%). See European Parliament, 2019 European Election Results, available at <https:// election-results.eu/turnout/> accessed 29 October 2019.

92 United Nations Economic Commission for Europe (UNECE) - Convention on Access to Information, Public Participation in Decision-Making and Access to Justice in Environmental Matters (adopted on 25 June 1998 in Aarhus), available at <www.unece.org/fileadmin/ DAM/env/pp/documents/cep43e.pdf> accessed 29 October 2019. 
lowed with a progressive case law, for instance: by granting broad legal standing for environmental NGOs and ensuring that the public has wide access to justice; ${ }^{93}$ by recognising certain substantive rights for individuals and NGOs stemming from EU secondary legislation; ${ }^{94}$ by imposing the obligation on Member States' courts to interpret national law implementing EU environmental law 'to the fullest extent possible' consistently with the objectives of the Aarhus Convention; ${ }^{95}$ or by interpreting broadly the requirement that the costs of judicial proceedings must not be prohibitively expensive in order to safeguard the right to effective remedy in environmental matters. ${ }^{96}$

However, despite many positive developments, there are equally many shortcomings in the Aarhus framework that impact environmental justice in the EU, both at the level of individual Member States and at the supranational level between different Member States. ${ }^{97}$ Many of these shortcomings are embedded in the Convention's historical origins. There is an inherent 'normative mismatch' in the structure of the Aarhus regime of environmental democracy: it tries to accommodate and balance manifold diverging interests, including democratisation, openness and transparency in environmental matters on the one hand, and the neoliberal-capitalist model of economic development with the protection of private commercial and market interests on the other. ${ }^{98}$ This is reflected,

93 Case C-263/08 Djurgården-Lilla Värtans Miljöskyddsförening ECLI:EU:C:2009:631; Case C-115/09 Bund für Umwelt und Naturschutz Deutschland, Landesverband Nordrhein-Westfalen ECLI:EU:C:2011:289.

94 Case C-237/07 Dieter Janecek $v$ Freistaat Bayern ECLI:EU:C:2008:447 (recognising the right of private parties whose health is impaired to have an action plan on ambient air quality drawn up by public authorities); Joined Cases C-165/09 to C-167/09 Stichting Natuur en Milieu and Others ECLI:EU:C:2011:348.

95 Case C-240/09 Lesoochranárske zoskupenie (Slovak Bears) ECLI:EU:C:201 1:125.

96 Case C-427/07 Commission v Ireland ECLI:EU:C:2009:457; Case C-260/11 David Edwards and Lilian Pallikaropoulos $v$ Environment Agency ECLI:EU:C:2013:221; Case C-530/11 Commission v United Kingdom ECLI:EU:C:2014:67.

97 Most notable are obstacles to access national courts, gaps in national implementation of EU environmental laws and policies, problems in realising the Aarhus rights in practice in the EU and in Member States, etc. See Commission, 'Commission Notice on Access to Justice in Environmental Matters' Communication C(2017) 2616 final 5-6: 'Individuals and NGOs are adversely affected by obstacles to access to national courts. [...] The most pressing implementation gaps across EU Member States are found in the policy fields of waste management, nature and biodiversity, air quality, and water quality and management'. See also Commission, 'The EU Environmental Implementation Review: Common Challenges and How to Combine Efforts to Deliver Better Results' Communication COM(2017) 63 final, which, indicatively, does not explicitly tackle or elaborate possible environmental or social justice issues but does emphasise that '[w]eak implementation generates high societal, economic and environmental costs and it creates an uneven playing field for businesses' 2 (emphasis added).

98 Michael Mason, 'Information Disclosure and Environmental Rights: The Aarhus Convention' (2010) 10(3) Global Environmental Politics 10. 
for instance, in more stringent requirements for public access to environmental information in EU law than is prescribed in the Aarhus Convention, and consequently more protection granted for economic interests, ${ }^{99}$ or 'the tendency of EU institutions to shield corporate actors from Aarhus responsibilities ${ }^{\prime 100}$ at the expense of the protection of the public good.

Furthermore, Aarhus's three pillars of environmental democracy assume that all Member States, albeit 'separate' (as sovereign countries), are 'equal' in relevant aspects, and thus envisage one-size-fits-all rules and standards. The formalism of this approach disregards a couple of things that may be observed through the existing centre-periphery divide in the EU.

The first asymmetry concerns the procedural dimension of environmental justice and encompasses several issues. The influence of big businesses with homogenous, concentrated interests on environmental decision-making is disproportionate in comparison to larger, heterogeneous groups (civil society, environmental NGOs) with diffuse interests. ${ }^{101}$ As the EU 'crits' have suggested, the interests of companies and industries from the EU centre are overrepresented in EU decision-making, both formally (through the structural bias of the EU internal market in their favour, and the EU's institutional framework more generally) and informally (through lobbying and greater representation in the EU centres of power), whereas EU peripheral states are in many respects underrepresented in the EU institutional framework.

One peculiar characteristic of environmental law is the dependence of its enforcement on private actors. ${ }^{102}$ There is a lack of financial incen-

99 See, generally, Peter Oliver, 'Access to Information and to Justice in EU Environmental Law: The Aarhus Convention' (2013) 36(5) Fordham International Law Journal 1423. Other discrepancies between the Aarhus and the EU frameworks include an additional exception for denying access to environmental information ('the protection of [...] the financial, monetary or economic policy of the EU or a Member State'), see Article 4(1)a of Regulation (EC) No 1049/2001 of the European Parliament and of the Council of 30 May 2001 regarding public access to European Parliament, Council and Commission documents; and omitting in Article 4(2) of the same Regulation the Aarhus Convention's requirement that the "confidentiality of commercial and industrial information is protected by law, in order to protect a legitimate economic interest' (emphasis added), before access to environmental information in order to protect the 'commercial interests of a natural or legal person' can be denied.

100 Michael Mason, 'So Far but No Further? Transparency and Disclosure in the Aarhus Convention' in Aarti Gupta and Michael Mason (eds), Transparency in Global Environmental Governance: Critical Perspectives (MIT Press 2014) 97.

101 In general on the theory of public goods, interest groups and collective action, see the seminal works of American political economist Mancur Olson, The Logic of Collective Action: Public Goods and the Theory of Groups (Harvard University Press 1965) and The Rise and Decline of Nations: Economic Growth, Stagflation, and Social Rigidities (Yale University Press 1982).

102 Ludwig Krämer, 'The Environmental Complaint in EU Law' (2009) 6(1) Journal for European Environmental and Planning Law 13: 'Strong environmental groups which could 
tives for individuals and economic operators to comply with or pursue enforcement of the EU environmental regulation, unlike in other regulatory areas such as the internal market or antitrust. ${ }^{103}$ This directly affects the quality of the system of monitoring the application of environmental laws in the EU, with Member States of the periphery facing greater difficulties due to lack of compliance and engagement by private actors. As Krämer notes:

Little attention is granted, until today, to the practical organization of monitoring the application of environmental law. In Germany, the Länder execute federal environmental legislation as matters of their own. There is no mechanism to monitor, whether this execution is properly done, and there is, in practice, no mechanism to call a Land to order when federal environmental legislation is not fully complied with. This approach is based on the concept that citizens and economic operators will follow the rule of law, once it is expressed in the form of legislation. The situation in many EU Member States - one may quote Greece, Italy, Spain, Portugal, Ireland, and more or less all of the twelve Member States which joined the European Union since 2004 - is different. ${ }^{104}$

Apart from the quality of the civil and business sector, another issue relevant in this context is the level of citizens' engagement in public and environmental matters, which differs between the EU centre and periphery. Reports on the share of active citizens ${ }^{105}$ in the total population of EU Member States seem to disclose a gap between the centre and the periphery. ${ }^{106}$ There is a similar centre-periphery divide regarding citizen participation in formal voluntary activities. ${ }^{107}$ This gap in active

contribute to the effective application of [EU] environmental law, lack; this feature makes the environmental sector different from most other economic or social sectors, where strong interests - professional bodies, trade unions, competitors, trade and industry associations, farmers' associations - promote the defense of their respective interests. All the more is the environment dependent on the commitment of the civil society to preserve and protect it'.

103 Commission, 'Proposal for a Directive on Access to Justice in Environmental Matters' COM(2003) 624 final.

104 Krämer (n 102) 13.

105 Eurostat (n 79) 111: 'Active citizenship describes people who decide to get involved in democracy at all levels, from local communities, through towns and cities to nationwide activities. Indeed, participative democracy requires people to get involved and to play an active role in political organisations or supporting various causes with a commitment to improve the welfare of society'.

106 ibid, 112: 'Across the EU Member States, the share of active citizens peaked in 2015 in France $(24.6 \%)$, followed by Sweden $(22.1 \%)$, the Netherlands (17.8\%) and Finland $(17.0 \%)$ [...] At the other end of the range, less than $5.0 \%$ of the population in 2015 were active citizens in Belgium, Hungary, the Czech Republic, Bulgaria, Romania, Slovakia and Cyprus - which had the lowest proportion (2.1\%)'.

107 ibid, 118-119: 'There were nine Member States where fewer than 1 in 10 adults participated in formal voluntary activities in 2015 - they were principally located in eastern and southern Europe, with the lowest share recorded in Romania (3.2\%)'. 
citizenship closely follows the income gap, ${ }^{108}$ so the centre-periphery divide here should perhaps not come as a great surprise. Moreover, since in the majority of Member States 'the cost of the judicial procedures is considered to be an obstacle to environmental justice - or at least to have a dissuasive effect thereupon, ${ }^{109}$ the existing income gap will arguably affect the exercise of the Aarhus right to access courts differently in the EU centre and periphery.

Furthermore, the type of main problems that communities in different Member States bear reveals different environmental harms faced by the EU centre and periphery. This was one of the indicators of environmental injustice in the US identified by Professor Paul Mohai: he noted how responses to the question of the most important environmental problem in the USA vary between white and black respondents, where the former group singled out overconsumption of natural resources while the latter group identified pollution. ${ }^{110}$ Similarly in the EU, respondents from the core Member States predominantly identify climate change as the most important environmental issue they face, whereas respondents from the EU periphery almost always single out air pollution and waste. ${ }^{111}$ Another similar, almost perfect, centre-periphery divide in responses was recorded for citizen attitudes concerning the global importance of climate change. ${ }^{12}$

\footnotetext{
108 ibid, 115: '[A]n analysis of active citizenship by income quintile [...] reveals that a larger proportion of people with higher incomes were active citizens'.

109 Jan Därpö, 'Effective Justice? Synthesis of the Report of the Study on the Implementation of Articles 9.3 and 9.4 of the Aarhus Convention in the Member States of the European Union' 2013-10-11/Final (2013) available at <http://ec.europa.eu/environment/aarhus/pdf/synthesis\%20report\%20on\%20access\%20to\%20justice.pdf> accessed 30 October 2019.
}

110 Bill Kubota, 'Fighting for Air in Southwest Detroit' (Detroit Journalism Cooperative, 6 December 2017) available at <www.detroitjournalism.org/2017/12/08/fighting-air-48217/> accessed 30 October 2019 (Paul Mohai appears in the video at 8:10).

111 Special Eurobarometer 468, Attitudes of European Citizens towards the Environment (Summary, October 2017) 6: 'In 11 Member States, climate change is ranked as the most important environmental issue, while air pollution is most frequently chosen as an important issue in eight countries; in France, an equal proportion of respondents choose these two issues. In seven countries, the growing amount of waste is considered as the most important environmental issue, while in one country (Portugal) agricultural pollution and soil degradation is the most frequently-chosen issue'. Among available responses, 'climate change' is selected by respondents in eight states of the centre, two semi-peripheral and one peripheral Member State (Cyprus); 'air pollution' by respondents in six states from the periphery, two semi-peripheral and a single core Member State (Belgium); 'growing amount of waste' by respondents in seven states from the periphery.

112 Special Eurobarometer 459, Climate Change (March 2017) 7-8 and 12: The question was about 'climate change as the single most serious problem facing the world'; the results showed that '[i]n three Member States, at least a quarter of respondents say that climate change is the most serious problem: Sweden (38\%), Denmark $(29 \%)$ and the Netherlands $(27 \%)$. At the other end of the scale, fewer than one in ten respondents consider it to be the most serious problem in 13 Member States, with the lowest scores in Portugal and Greece (both 4\%) and the Czech Republic and Poland (both 6\%)'. 
These data and indicators, showing different levels of public participation and different attitudes toward the most pressing environmental problems between the EU centre and periphery, hint at some environmental justice issues between the two groups of EU countries. Therefore, EU procedural environmental laws implementing the Aarhus Convention's first two pillars (concerning access to environmental information and public engagement in environmental matters), when assuming formal equality between the Member States, fail to consider the existing differences. Hence, this procedural dimension falls short of ensuring substantive environmental justice for citizens of the EU periphery.

The second asymmetry concerns the corrective dimension of environmental justice. Most importantly, in access to justice, 'regulated entities' - and, to reiterate, EU legal and market structures privilege companies and businesses from the centre - have more access to review acts of the EU institutions than 'regulatory beneficiaries', that is, citizens and environmental NGOs. Here, especially problematic is the CJEU's narrow interpretation of standing to challenge decisions of the EU institutions. Unlike in other policy areas where it is considered to have progressively protected different 'oppressed' groups and individuals by expanding and ensuring enforcement of their rights, ${ }^{113}$ in environmental matters it adopts a strikingly different, incomprehensibly regressive approach. More specifically, the Plaumann test, ${ }^{114}$ devised long ago by the Court to regulate who gets to access EU courts to challenge EU acts, has virtually barred environmental NGOs from standing. ${ }^{15}$ This test requires from

113 Perišin (n 39) 166: 'The Court of Justice has played a pivotal role in granting rights to the "oppressed". Through its case law, it has developed a number of individual rights such as non-discrimination on the grounds of nationality, gender, age, disability (including obesity), etc. Furthermore, the Court's constructs of direct effect, supremacy, interpretative effect and some other characteristics of EU law have contributed to the actual enforcement of rights' (footnotes omitted). In addition, '[i]n synergy with the ideology of European integration, the Court has taken a number of progressive steps and has pioneered the protection of many individual and group rights. Some groups still perceive themselves as outsiders or indeed are outsiders to European integration, so there is still work to be done, and to some extent this work can be done by the Court' (174).

114 Case 25-62 Plaumann \& Co v Commission ECLI:EU:C:1963:17. Case T-585/93 Stichting Greenpeace Council (Greenpeace International) and Others $v$ Commission ECLI:EU:T: 1995: 147, paras 50-60, confirmed that Plaumann 'remains applicable whatever the nature, economic or otherwise, of those of the applicants' interests which are affected' (reiterated in Joined Cases T-236/04 and T-241/04 European Environmental Bureau (EEB) and Stichting Natuur en Milieu $v$ Commission ECLI:EU:T:2005:426). In the post-Aarhus era, the inability for environmental interests to ground legal standing was reasserted in Case T-91/07 WWF-UK Ltd v Council ECLI:EU:T:2008:170, para 82: '[A]ny entitlements which the applicant may derive from the Aarhus Convention and from Regulation No $1367 / 2006$ are granted to it in its capacity as a member of the public. Such entitlements cannot therefore be such as to differentiate the applicant from all other persons within the meaning of the [existing] case law'.

115 Mariolina Eliantonio, 'Towards an Ever Dirtier Europe? The Restrictive Standing of Environmental NGOs Before the European Courts and the Aarhus Convention' (2011) 7 
claimants [...] to demonstrate that they were 'directly' and 'individually' concerned with the challenged act, conditions that were never fulfilled in cases related to enforcement of environmental law. [...] [O]ne could note that the Plaumann test is shaped according to traditional individual rights and personal interests. By contrast, environmental cases are inherently underpinned by public interest and support the preservation of common goods. ${ }^{116}$

This judicially constructed test and 'the prerequisite of individuality' thus introduced, De Sadeleer and Poncelet stress, 'had a chilling effect on potential applicants seeking to challenge acts of Union law which had an impact on the quality of the environment'. ${ }^{117}$ Unfortunately, any change in judicial doctrine regarding the standing of 'regulatory beneficiaries' to challenge the legality of EU environmental laws seems rather unlikely. The Court appears rather unenthusiastic about the Aarhus Convention's application in relation to the EU institutions as compared to the Member States' institutions, ${ }^{118}$ or allowing public engagement to protect the environment as opposed to economic interests. ${ }^{119}$

In the meantime, as a matter of international law, with the CJEU's restrictive treatment of legal standing, the Union, a self-proclaimed global champion of the rule of law, remains in violation of the Aarhus Convention's requirements on access to justice. ${ }^{120}$ This 'inconvenient truth' was

Croatian Yearbook of European Law and Policy 84: 'By applying the restrictive Plaumann test to the actions brought by environmental NGOs, the European courts have, to date, significantly curtailed access to justice to challenge EU measures affecting the environment. In fact, in none of the cases brought at the European level have environmental NGOs ever been granted standing'.

116 Nicolas De Sadeleer and Charles Poncelet, 'Protection Against Acts Harmful to Human Health and the Environment Adopted by the EU Institutions' (2012) 14 Cambridge Yearbook of EU Law 179-180 (emphasis added, footnotes omitted).

117 ibid, 179.

118 Laurens Ankersmit and Benedikt Pirker, 'Review of EU Legislation under EU International Agreements Revisited: Aarhus Receives another Blow' (European Law Blog, 17 November 2015) available at <https://europeanlawblog.eu/2015/11/17/review-of-eu-legislation-under-eu-international-agreements-revisited-aarhus-receives-another-blow/> accessed 30 October 2019 ('The conclusion one has to draw at this point is that the Court is to quite some extent dissatisfied with the drafting of the Aarhus Convention, and expresses it through its reticence to give effect to its provisions whenever the EU institutions are potentially at risk. However, such selective binding effect of the Convention is hardly dogmatically tenable. Does the Court have a legitimate reason to differentiate between the obligations resulting from the Convention for the Member States and those for the EU?').

119 Ludwig Krämer, 'Access to Environmental Justice: The Double Standards of the ECJ' (2017) 14(2) Journal for European Environmental and Planning Law (demonstrating that the CJEU 'is much stricter with regard to the admissibility of actions which try to protect the environment' than regarding actions brought by industry and businesses when their economic and financial interests are at stake).

120 Charles Poncelet, 'Access to Justice in Environmental Matters: Does the European Union Comply with its Obligations?' (2012) 24(2) Journal of Environmental Law 287 (ques- 
recently confirmed by the Aarhus Convention Compliance Committee. ${ }^{121}$ Internally - rather 'paradoxically' and 'perversely'122 - there is even less room for individuals and NGOs from both the EU's centre and periphery to hold the EU institutions legally accountable for their actions affecting the environment. ${ }^{123}$ As a consequence, "there is a strong possibility that [environmental] measures taken by the EU authorities were enforced in spite of their potential unlawfulness. This in turn may affect the quality of the environment. ${ }^{124}$

Another issue impairing corrective environmental justice in the EU concerns the efficiency of national justice systems. The vast majority of EU laws are enforced and administered in a decentralised manner, that is, by the Member States. In the EU, this is known as 'executive federalism'. ${ }^{125}$ Unlike law-making powers, the Union lacks comprehensive exec-

tioning "whether the EU legal system complies with the letter and the spirit of the Aarhus Convention'); Benedikt Pirker, 'Access to Justice in Environmental Matters and the Aarhus Convention's Effects in the EU Legal Order: No Room for Nuanced Self-executing Effect?' (2016) 25(1) Review of European, Comparative and International Environmental Law 81 (criticising 'the Court's overtly rigid jurisprudence' due to which the Aarhus Convention 'cannot serve as a benchmark to review the very same Convention's implementing measure at EU level, the Aarhus Regulation').

121 Aarhus Convention Compliance Committee, Findings and recommendations of the compliance committee with regard to communication ACCC/C/2008/32 (Part II) concerning compliance by the European Union, adopted by the Compliance Committee on $17 \mathrm{March}$ 2017, available at <www.unece.org/fileadmin/DAM/env/pp/compliance/C2008-32/Findings/C32_EU_Findings_as_adopted_advance_unedited_version.pdf $>$ accessed 30 October 2019. For a commentary, see Benedikt Pirker, 'Implementation of the Aarhus Convention by the EU: An Inconvenient Truth from the Compliance Committee' (European Law Blog, 24 April 2017) available at <https://europeanlawblog.eu/2017/04/24/implementation-of-the-aarhus-convention-by-the-eu-an-inconvenient-truth-from-the-compliance-committee/> accessed 30 October 2019.

122 Eliantonio (n 115) 76: '[T]he European Courts have interpreted the individual concern criterion so narrowly (and, one could argue, somewhat paradoxically) that environmental NGOs have in every case been refused standing to challenge EU institutions' decisions, exempting essentially these decisions from judicial scrutiny. [...] The application of the Plaumann test to environmental measures has the perverse effect that the higher the number of individuals affected by EU measures (and hence, one could argue, the more potentially dangerous the EU measure is), the less chance there will be that standing will be granted'.

123 De Sadeleer and Poncelet (n 116) 183: 'In essence, most environmental measures do not create situations that are "peculiar" to anyone within the meaning of the Plaumann doctrine. In fact, the condition of individuality as construed by the Court was virtually impossible to fulfil. In other words, environmental measures were immune from judicial review initiated by individuals'.

124 ibid.

125 Koen Lenaerts, 'Constitutionalism and the Many Faces of Federalism' (1990) 38(2) American Journal of Comparative Law 230-233; Robert Schütze, 'From Rome To Lisbon: "Executive Federalism" in the (New) European Union' (2010) 47(5) Common Market Law Review 13851386: 'The Union must therefore extensively rely on the Member States to administer federal law. [...] [T]he Union's executive powers are co-extensive with its legislative powers; yet, the Union's executive powers are only subsidiary to the Member States' powers'. 
utive powers. Therefore, between the citizens and EU environmental laws stand national public authorities. Their acts and decisions implementing EU environmental laws are then reviewable before national courts.

However, in the area of environmental procedural rights, Member States have so far opposed, due to subsidiarity issues, the adoption of a Directive on access to justice in environmental matters that would implement the Aarhus Convention's third pillar uniformly in national legal systems. ${ }^{126}$ Hence, differences in Member States regarding the administration and judicial enforcement of EU laws impact environmental justice in different parts of the EU. This was similarly recognised by Harper, Steger and Filcak when they noted that

The EU provides an emerging framework for the promotion of environmental protection, human rights and health. [...] Serious EU efforts in these realms, however, will require an elaborated regulatory framework that specifically targets environmental justice. Furthermore, asserting a framework for such important measures does not always guarantee implementation, which can be challenging for new member states due to various constraints, including economic and administrative barriers. ${ }^{127}$

Almost as a rule, Member States of the centre have greater administrative capacities ${ }^{128}$ and enjoy on average a more efficient, quality and independent judiciary compared to the EU periphery. ${ }^{129}$ Illustratively, the 'quality of government' index that combines variables such as corruption, impartiality, quality of public services and the rule of law recently showed that there still exist wide regional differences in the quality of government between the Western and Northern EU Member States on the one hand and the Eastern and Southern ones on the other. ${ }^{130}$

So, here we reach a similar conclusion as that concerning the distributive inequalities in environmental matters discussed earlier: without substantive requirements for environmental justice that would take

\footnotetext{
126 Krämer (n 102) 17.

127 Harper, Steger and Filcak (n 36) 256 (emphasis added, references omitted).

128 Nicholas Charron and Victor Lapuente, 'Quality of Government in EU Regions: Spatial and Temporal Patterns' (2018) QOG The Quality of Government Institute University of Gothenburg, Working Paper Series 2018:2, available at <https://qog.pol.gu.se/digitalAssets/1679/1679869_2018_1_charron_lapuente.pdf> accessed 30 October 2019.

129 Commission, '2018 EU Justice Scoreboard with Factsheets. Communication from the Commission to the European Parliament, the Council, the European Central Bank, the European Economic and Social Committee and the Committee of the Regions' COM(2018) 364 final, available at <https://ec.europa.eu/info/publications/2018-eu-justice-scoreboard_en> accessed 30 October 2019.

130 Charron and Lapuente (n 128); see also Nicholas Charron, Lewis Dijkstra and Victor Lapuente, 'Regional Governance Matters: Quality of Government within European Union Member States' (2014) 48(1) Regional Studies 68.
} 
into account the centre-periphery divide in the EU as presented in this part, the other two dimensions (procedural and corrective) will be differently (in)effective in different parts of the EU, with the EU periphery being comparatively worse off in many respects than the EU centre. Due to its formalistic approach, then, the Aarhus regime as implemented in the EU fails to address appropriately existing distributive environmental injustice. Of course, the comparative lack of civic engagement or compliance by private actors in the periphery, or for that matter a less efficient administration and judiciary in the EU periphery, is not in and of itself unjust. However, the procedural and corrective avenues for remedying the existing environmental inequalities failing to take into account the EU centre-periphery gap in their operation in effect forecloses the EU periphery's 'aspirations and claims for protection against [environmental] harm'. ${ }^{131}$ And this is what is unjust.

Could the EU legal instruments somehow be adapted to address environmental injustice (in all three dimensions) among the EU countries, that is, make a 'shift' from formal to substantive equality? I return to this question in Section 5. But first, a word on the possible explanation of the causes of environmental injustice in the EU.

\section{What kind of environmental injustice is there in the EU centre- periphery gap?}

In this part, I will try to conceptualise further the environmental injustice identified and linked to the centre-periphery divide in the EU. At first, it would seem clear that if the arguments offered in the previous section were to be accepted, the dominant explanation for the recognised environmental injustice would be socio-economic factors (hence, environmental classism) and not racial factors (or environmental racism) as in the US. ${ }^{132}$ In other words, explaining environmental injustice between different Member States would need to focus primarily on the inequalities in economic development and wealth. But this, in my view, does not completely foreclose factors other than socio-economic ones as a supporting explanation of the causes of environmental injustice in the EU, as proposed in this paper. Let me unpack this.

First, we need to go back to other American intellectual movements that in many ways followed the CLS movement mentioned in the opening

\footnotetext{
131 Kukovec (n 37).

132 Similarly, Laurent (n 13) 1849: '[E]nvironmental justice issues are not likely in Europe to be perceived, analyzed and framed in racial and ethnic terms but in terms of social categories. It should not be understood as meaning that environmental inequalities do not have a racial dimension in Europe (they of course do, like all social inequalities in racially diverse societies [...])' (emphasis added).
} 
part and added a distinctive layer to its critique of legal formalism. Here I have in mind the identity critique of law offered by the Critical Race Theory (CRT) and feminist legal theory, both providing useful analytical tools for examining the role of law in establishing and perpetuating societal hierarchies. These critical theories to a large extent reflected Antonio Gramsci's ideas of legal hegemony and law's legitimation of exploitations and oppressions: Gramsci saw

hegemony [as] the permeation throughout civil society [...] of an entire system of values, attitudes, beliefs, morality, etc. that is in one way or another supportive of the established order and the class interests that dominate it. [...] To the extent that this prevailing consciousness is internalized by the broad masses, it becomes part of 'common sense'. [...] $[\mathrm{H}]$ egemony work[s] in many ways to induce the oppressed to accept or 'consent' to their own exploitation and daily misery. ${ }^{133}$

In this fashion, the CRT criticised ahistorical and decontextualized legal narratives. ${ }^{134}$ It 'examined the role of liberal-capitalist ideology in maintaining an unjust racial status quo' and aimed to deconstruct 'traditional interests and values [that] serve as vessels of racial subordination'. ${ }^{135}$ Similarly to their CLS counterparts, CRT scholars were fundamentally suspicious about 'dominant legal claims of neutrality, objectivity, color blindness, and meritocracy.'.136 They especially questioned 'the basic legitimacy of the free market' that is alleged to operate 'fairly and impartially'. ${ }^{137}$ (That the CRT indeed intersects with the environmental

133 See Gottlieb, Bix, Lytton and West (n 16) 632, quoting Edward Greer, 'Antonio Gramsci and Legal Hegemony' in David Kairys (ed) The Politics of Law: A Progressive Critique (Third Edition, Basic Books 1998) 304-309 (emphasis added).

134 See Charles R Lawrence III, Mari J Matsuda, Richard Delgado and Kimberlé Williams Crenshaw, 'Introduction' in Mari J Matsuda, Charles R Lawrence III, Richard Delgado and Kimberlé Williams Crenshaw (eds), Words That Wound. Critical Race Theory, Assaultive Speech, and the First Amendment (First Edition, Routledge 1993) 1-15, for an explanation of what the Critical Race Theory is.

135 ibid, 5-6.

136 ibid, 6.

137 Kimberlé Williams Crenshaw, 'Race, Reform, and Retrenchment: Transformation and Legitimation in Antidiscrimination Law' (1988) 101(7) Harvard Law Review 1380: 'Race consciousness also reinforces whites' sense that American society is really meritocratic and thus helps prevent them from questioning the basic legitimacy of the free market. Believing both that Blacks are inferior and that the economy impartially rewards the superior over the inferior, whites see that most Blacks are indeed worse off than whites are, which reinforces their sense that the market is operating "fairly and impartially"; those who should logically be on the bottom are on the bottom. This strengthening of whites' belief in the system in turn reinforces their beliefs that Blacks are indeed inferior. After all, equal opportunity is the rule, and the market is an impartial judge; if Blacks are on the bottom, it must reflect their relative inferiority. Racist ideology thus operates in conjunction with the class components of legal ideology to reinforce the status quo, both in terms of class and race' (emphasis added, footnotes omitted). 
justice movement, as I believe it does, one is lead to think after reading works of scholars like Richard Delgado and Carmen Gonzalez.)

Moreover, feminist legal scholars added to the CRT's critique of law the following dilemma that I find particularly instructive for my later proposition: is ethnicity to race what gender is to sex, meaning a paradigm social construct (former) to a (putatively) biological category (latter) ${ }^{138}$ Are the two (ethnicity and race) easily severed after all?

I wonder whether any kind of arguments along these lines could be made when discussing the EU centre-periphery divide (and not only in environmental matters, which is what concerns me the most here). After all, EU (environmental) law is most often ahistorical, decontextualised and technocratic. ${ }^{139}$ Could it have any role in, if not establishing, then perpetuating or legitimising the identified injustice?

I suppose there could be several responses to this. Of those, one position would be to deny the existence of any environmental injustice between the EU centre and periphery. This basically rejects the very premises offered here, so any conclusion on the root causes or contemporary drivers of that injustice would likewise have to be rejected.

Another position would be to acknowledge the existence of some sort of environmental injustice, of some degree, at this level, which would at the same time fail to see any wrong of the EU structures in establishing or perpetuating that injustice. A proponent of this position would cling to the asserted 'neutrality, objectivity, and meritocracy' of the EU, its law and its institutional setup, and profess the 'fair, unbiased and impartial' operation of the EU market. These narratives, if you recall, were attacked convincingly by European critical legal scholars who unmasked the structural hierarchies and inequalities that lie behind the façade of such a market-centred ideology.

Yet another position would be to acknowledge the underlying injustice but to take it as something inevitable, or, even more cynically, as something deserved. Perhaps this would be a marginal position that no one would ever adopt (at least not publicly), so I might be after a straw man with this one. But not necessarily. Indeed, there might be some who share the view of the ex-World Bank chief economist Lawrence Summers

\footnotetext{
138 Remarks by Professor Catharine A MacKinnon, a leading contemporary feminist legal theorist and political philosopher, during a lecture at the University of Michigan Law School (March 2019). Compare with her textbook Sex Equality (Third Edition, West Academic Publishing 2016) 61 (fn 1): "This book uses the terms "race" and "ethnicity" interchangeably, as it is the social meaning of race, i.e. ethnicity, in social systems of inequality, that is under discussion'.

139 Similarly, Gonzalez (n 22) 84, claims that 'the discourse of international environmental law is often ahistorical and technocratic'.
} 
about the economic logic behind having underdeveloped, under-polluted countries bearing the greater burden of environmental degradation. ${ }^{140}$ So, in the EU context, one would have the peripheral Member States, being less developed and (historically) less polluted than the EU centre, with a greater share of (contemporary) environmental harms and burdens (some of which were discussed in Section 3, such as a lower quality of ambient air, worse environmental and living conditions, or greater energy poverty and air pollution-related diseases and deaths). There could indeed be some economic logic behind this.

Or, the argument could be that, in 'a meritocratic, fair and impartial' Union of equals, if the EU periphery is indeed inferior in certain matters, it must be doing something wrong. '[T]hose who should logically be on the bottom are on the bottom. ${ }^{141}$ This view, I believe, seems more present in the current discourse about the EU. It builds upon certain stereotypes, which come with prejudicial connotations, about Member States of the EU periphery. These stereotypes might operate as an engine for entrenching hierarchies that European CLS scholars are writing about. Furthermore, these essentially 'ethnic' stereotypes are grounded in a set of false dichotomies that can be used to legitimise the underlying injustices and oppression. So, false dichotomies that exist about the EU periphery (and are often juxtaposed to the EU centre) include the following characterisations of their citizens: easy-going vs serious; corrupted vs trustworthy, or lazy vs hard-working, or (financially) reckless vs (financially) responsible; ${ }^{142}$ xenophobic vs cosmopolitan; ${ }^{143}$ simpleminded vs open-minded and well-educated; etc. (Note here that the stereotyping is equal: it is present for both core and peripheral EU nations. But substantively, the resulting stereotypes are unequal: for the former they are positive or largely neutral, for the latter negative; the first denote dominance, the second submission).

Some of the false dichotomies, like Eastern European plumbers (manual labourers) vs Western European bankers (liberal professionals), have featured significantly in recent major political events in the EU. For instance, the Polish plumber hysteria that was omnipresent in Western

\footnotetext{
140 Jim Vallette, 'Larry Summers' War Against the Earth' (CounterPunch, 15 June 1999): ('[A] given amount of health impairing pollution should be done in the country with the lowest cost, which will be the country with the lowest wages. I think the economic logic behind dumping a load of toxic waste in the lowest wage country is impeccable and we should face up to that').

141 Crenshaw (n 137).

142 Here I have in mind narratives on the Greek sovereign debt crisis.

143 Here I have in mind narratives on the failure of the EU's Dublin asylum regime due to the rejection of refugee allocation quotas by (most prominently) Central and Eastern European Member States.
} 
Europe and ultimately contributed to the failure of the proposed EU Constitutional Treaty in national referendums in two 'core' Member States (France and the Netherlands) in 2005. ${ }^{144}$ As Böröcz and Sarkar further remarked:

It would seem that the trope of the Polish Plumber played quite a historic role in holding back the post 'nation-state' transformation of western Europe [...] the increasingly demonized figure of the east-European-worker dominated discursive space about labor policy, social rights, and eventually, European Union membership. ${ }^{145}$

Or, the UK's 2016 referendum to leave the Union that was in part fuelled by the concerns about the immigration of cheap labour from the EU periphery. ${ }^{146}$ Comparing the two events, Ballinger argued that

The stock character of the 'Polish plumber' who has migrated to Western Europe thanks to the policies of EU enlargement, for example, embodies the fear of a displaced 'Eastern Europe' now lurking in the heart of France or the United Kingdom. Whereas in the mid-2000s French anxieties about Polish workers were mocked gently [...] by the time of the 2016 Brexit vote the anxieties aroused by Polish plumbers had become deadly serious. ${ }^{147}$

So, similarly, in explaining environmental injustice as depicted in this paper, the argument would be that 'they [in the EU periphery] must be doing something wrong' in environmental affairs: for instance - and here the stereotypes appear - they are bio-unfriendly, ecologically or environmentally 'unconscious' and ignorant, unaware of nature's fragility,

\footnotetext{
144 József Böröcz and Mahua Sarkar, 'The Unbearable Whiteness of the Polish Plumber and the Hungarian Peacock Dance around "Race”" (2017) 76(2) Slavic Review 309.

145 ibid, 309-311.

146 See Perišin (n 39) 155: '[Brexit voters] voted to leave the EU, believing that by blocking the inflow of other EU citizens, primarily those from Central and Eastern Europe, and by stopping the immigration of third-country nationals, they could regain some benefits that existed in a closed market'; Böröcz and Sarkar (n 144) 311: 'The tone of the British [Brexit] conversation was considerably more ferocious than the French. The frequency of acts of physical violence against Poles increased dramatically' (footnotes omitted); Vanessa Quick, 'Beneficial immigration' (The German Times, September 2007): 'The Polish plumber has come to symbolize the Western Europeans' fear of an invasion of cheap Eastern European labor threatening their jobs'; Elisabeth Braw, "Brexit" debate: Could Britain get by without the "Polish Plumber"?' (Christian Science Monitor, 25 February 2016) available at <www. csmonitor.com/World/Europe/2016/0225/Brexit-debate-Could-Britain-get-by-withoutthe-Polish-Plumber > accessed 30 October 2019 ('Pro-Brexit campaigners blame Poles - and the tens of thousands of Romanians and Bulgarians who have joined them - for taking jobs and benefits from British workers. [...] Much like Mexican and Central American immigrants in the United States, Poles are seen as taking primarily unskilled jobs away from working-class Britons. Even worse, many Britons feel, is the fact that many Poles send the child benefit payments they receive here to their children in Poland').
}

147 Ballinger (n 47) 45-46. 
they support environmentally harmful practices and lifestyles, they are not 'green' enough, etc.

I wonder whether environmental injustice lying in the EU centre-periphery gap could somehow be conceptualised along these lines. I understand that a predominant driver of such injustice might still be socio-economic factors ('classism'). But, other drivers could nevertheless be instrumental in supporting this injustice. Perhaps it should not be regarded as pure 'racism' (as in the USA), so I would suggest understanding it at the supranational level, that is, the Union level, as 'ethnicism'. In this context, the term 'ethnicism' would contain prejudicial connotations and the above-mentioned stereotypes about the Member States of the EU periphery. Indeed, racism and stereotypes have already been acknowledged as supporting and legitimising environmental injustice at the micro-level in Europe: Harper, Steger and Filcak thus held that 'stereotypical representations of the Roma come to justify their economic and spatial marginalization'. ${ }^{148}$ Therefore, I propose as one way of viewing environmental injustice between different EU Member States (at the macro-level) as a combination of environmental 'classism' and 'ethnicism'. '[Ethnicist] ideology thus operates in conjunction with the class components of legal ideology to reinforce the status quo, both in terms of class and [ethnicity]. ${ }^{149}$ What would be the precise share of each intersecting phenomenon or their correlation in perpetuating or legitimising the environmental injustice in the EU is an open question; to go in either direction at this point, I admit, would be very speculative. However, since my main argument does not depend on resolving this, I leave the matter where it stands, satisfied with a preliminary attempt to conceptualise environmental injustice concealed in the EU centre-periphery divide in these terms.

To recapitulate at this point before moving on with the discussion: my argument (hardly spectacular or ground-breaking) is that: (i) the EU periphery is less responsible for historical and contemporary environmental harms in Europe than the EU centre; (ii) the EU periphery bears a greater contemporary environmental burden and suffers greater environmental harm than the EU centre; (iii) the current EU procedural and corrective framework is too formalistic to vindicate the EU periphery's claim for substantive environmental justice; (iv) the EU periphery has less political power than the EU centre to influence Union decision-making to address the environmental injustice in any of the three (distributive, procedural, corrective) dimensions; (v) environmental injustice between the Member States of the EU centre and periphery may be explained as a combination of environmental 'classism' and 'ethnicism'.

148 Harper, Steger and Filcak (n 36) 262.

149 Crenshaw (n 137). 
The concerned reader should not misread this: my argument is not that any of this is consciously or intentionally caused by the Member States of the EU centre, or EU law itself. In this sense, the argument is not guilt-ascribing, but rather responsibility-ascribing, as elaborated in the following section. But, mind you: environmental injustices nowadays do not follow from 'overt discriminatory animus', but from 'neutral decisions made within intrinsically biased' (economic, political, social) structures and reality. ${ }^{150}$ However, the claim is that: (vi) if, for whatever reason, the existing environmental inequalities remain unacknowledged and disregarded, the injustice against the EU periphery is effectively entrenched and perpetuated; (vii) if EU environmental regulation continues with 'business as usual' and is not adapted to address the environmental inequalities between the EU centre and periphery, the injustice against the latter is effectively legitimised through it.

\section{Environmental injustice and EU legal (constitutional) formalism}

Those who accept the existence of environmental injustice in the EU as proposed here might not only reject that the EU legal and political structures contribute to that injustice in any way; they could also argue that the Union has set up a framework that progressively decreases any sort of inequalities (including environmental ones) between the Member States. For instance, Steger holds that

The European Union has a foundation from which to encourage and support environmental justice. [...] [O]f the multiple streams linking human rights and the environment, the movement for environmental justice has finally come to the European Union. ${ }^{151}$

I, on the other hand, will claim in this section that the EU framework fails to properly ensure environmental justice in both respects: in general, that is, within its Member States individually, or in the context that I have set out in this paper. Note that this sort of negative argument ('what X does not do') might be unsatisfactory for some. They might expect the paper to provide a positive (perhaps empirical) argument about the role and contribution of EU (environmental) law, or of the Member States of the EU centre perhaps, in entrenching and perpetuating the identified injustice ('what X does'); or to offer fast-track, feasible solutions for adapting the EU framework to address environmental injustice between the EU centre and periphery and deliver substantive equality in this matter ('what X should do, and how'). However, not providing such an account should not be taken as proof of the inappropriateness of my

\footnotetext{
150 See Galalis (n 2).

151 Steger (n 32) 18-19.
} 
original argument just reiterated above. To dismiss my argument and counter it with this objection is logically unsustainable: the soundness or convincingness of the criticism of the present system cannot depend on its (in)ability to build a case for an alternative.

First I want to look at the EU constitutional and policy framework.

A 'constitutional charter'152 of the EU - the Union's founding Treaties and its Charter of Fundamental Rights ${ }^{153}$ - does not contain the term 'environmental justice'. It does mention the word 'environment' around thirty times (the word 'justice' appears several times more). The most important Treaty provisions concern EU environmental law and policymaking. ${ }^{154}$ Its key policy documents, such as the EU's current (seventh) Environment Action Programme, likewise seem to be silent on any notion of environmental justice. ${ }^{155}$

However, one may go further than a mere word search and add that 'the fact that the term environmental justice is not (yet) well-known in Europe does not necessarily mean that the European environmental policy is unjust'. ${ }^{156}$ So, it is necessary to look more carefully into other EU constitutional provisions and principles. Here are the most relevant ones.

Articles 11 TFEU mandates the EU authorities to integrate '[e]nvironmental protection requirements [...] into the definition and implementation of the Union's policies and activities, in particular with a view to promoting sustainable development'. Similarly, Article 37 of the EU

152 Referred to in this way for the first time in Case 294/83 Parti écologiste 'Les Verts' $v$ European Parliament ECLI:EU:C:1986:166, para 23.

153 Consolidated version of the Treaty on European Union (TEU) [2012] OJ C326/13; Consolidated version of the Treaty on the Functioning of the European Union (TFEU) [2012] OJ C326/47; Charter of Fundamental Rights of the European Union [2012] OJ C326/391.

154 The EU environmental regulation encompasses all sorts of issues: 'agriculture, air, chemicals, circular economy, cities, climate change, energy, industry, land and soil, marine and coastal environment, nature and biodiversity, noise, research and innovation, transport, waste, water'. See Commission, 'Energy, Climate change, Environment', available at $<$ https://ec.europa.eu/info/energy-climate-change-environment_en> accessed 31 October 2019. At the same time, the EU prides itself on having ensured for its citizens 'some of the world's highest environmental standards'. See Official website of the European Union, Environment, available at <https://europa.eu/european-union/topics/environment_en> accessed 31 October 2019: ('EU citizens benefit from some of the highest environmental standards in the world'. [...] 'The EU has some of the world's highest environmental standards, developed over decades').

155 Decision No 1386/2013/EU of the European Parliament and of the Council of 20 November 2013 on a General Union Environment Action Programme to 2020 'Living well, within the limits of our planet' [2013] OJ L354/171.

156 Bernard Vanheusden, 'Relevance of Environmental Justice for the Legal Framework in the European Union' (2010) 7(2) Journal for European Environmental and Planning Law 165. 
Charter (entitled 'Environmental Protection') states that '[a] high level of environmental protection and the improvement of the quality of the environment must be integrated into the policies of the Union and ensured in accordance with the principle of sustainable development'. Thus, for instance, Article 194 regulating the establishment and functioning of the EU energy market emphasises 'the need to preserve and improve the environment'.

Furthermore, Articles 191 and 192 TFEU enumerate principles and objectives of the EU environmental policy: (i) sustainable development, also defined in Article 3 TEU to include the EU's commitment to a 'high level of protection and improvement of the quality of the environment'; (ii) the precautionary principle; (iii) the preventive principle; (iv) the principle of rectification at source; and (v) the polluter pays principle.

Especially important for the further discussion is the reference to the diversity of environmental circumstances and levels of economic development of different EU's regions, which merits reproduction in full:

Union policy on the environment shall aim at a high level of protection taking into account the diversity of situations in the various regions of the Union. [...] In preparing its policy on the environment, the Union shall take account of: available scientific and technical data, environmental conditions in the various regions of the Union, the potential benefits and costs of action or lack of action, the economic and social development of the Union as a whole and the balanced development of its regions. ${ }^{157}$

And further:

Without prejudice to the principle that the polluter should pay, if a measure [...] involves costs deemed disproportionate for the public authorities of a Member State, such measure shall lay down appropriate provisions in the form of: temporary derogations, and/or financial support from the Cohesion Fund [...]. ${ }^{158}$

This, as I will argue later, seems to leave the only possibility for rectifying gaps between the EU centre and periphery through redistributive (environmental) policies. As Steger and Filcak wrote a decade ago:

The concept of economic and social cohesion [...] is reflected in the budget: structural policy is the second most heavily funded sector in

\footnotetext{
157 Article 191(2)(3) TFEU (emphasis added).

158 Article 192(5) TFEU (emphasis added). Recent numbers show that through the EU cohesion policy, ten Member States of the periphery have received EUR 365.2 billion since the first and the biggest wave of the eastern enlargement in 2004. See Commission, 'Growing Together: EU support to Member States that joined in 2004' (30 April 2019) available at <https://ec.europa.eu/commission/publications/growing-together-eu-support-memberstates-joined-2004_en> accessed 31 October 2019.
} 
the Union after the Common Agricultural Policy (CAP). There is a broad consensus on the need for greater cohesion. Cohesion policy is the way the European Union expresses solidarity and bears witness to the existence in the [Union] of a special model of development. Regional disparities have been increasing as a result of [...] enlargements, and it will be essential to help those regions in most need. Otherwise the Union may face the creation of new walls between prosperous and marginalized regions and the environmental consequences. ${ }^{159}$

The environmental provisions and principles listed above have been operationalised in a range of EU secondary legal acts, almost exclusively in directives, with only a few regulations. ${ }^{160}$ As a preliminary matter, to me it seems that there is no explicit doctrinal or textual ground for deriving environmental justice as understood in US scholarship (and presented in this paper) from the existing EU principles (although it could be argued that this is not a necessary requirement, since, illustratively, the US Constitution does not incorporate a similar textual reference, whereas US legal doctrine and administrative practices lend more support to the notion of environmental justice). In any event, highly imaginative, and certainly not uncontroversial, interpretative moves would be necessary as I propose later in this section. But first, a word on the shortcomings of the constitutional framework currently in place.

First of all, the existing constitutional environmental principles might complement environmental justice in the EU under some circumstances, but under others they might directly conflict with it. ${ }^{161}$ As Ole Pedersen convincingly demonstrates (hence I draw on his account closely in what follows), for instance, the precautionary principle could fail the expectations of substantive environmental justice primarily due to its focus on risk assessment and risk management tools that privilege

\footnotetext{
159 Tamara Steger and Richard Filcak, 'Articulating the Basis for Promoting Environmental Justice in Central and Eastern Europe' (2008) 1(1) Environmental Justice 52 (emphasis added).

160 See the repository of relevant EU environmental legislative and policy documents: European Environment Agency, 'Environmental Policy Document Catalogue', available at <www. eea.europa.eu/policy-documents> accessed 2 November 2019. See also Jasmina Kostelac Bjegovic, 'Handbook on the Implementation of EU Environmental Legislation' (Publications Office of the EU 2016) available at <https://op.europa.eu/en/publication-detail/-/publication/2b832b9d-9aea-11e6-868c-01aa75ed7lal > accessed 2 November 2019.

161 Ole W Pedersen, 'Environmental Principles and Environmental Justice' (2010) 12(1) Environmental Law Review 26: '[A] comparison [of environmental principles] with environmental justice gives rise to conflicts as well as conformity'. The same argument would hold for the US regulatory context too, as witnessed by references to the US scholarship in the following part. Unfortunately, in order not to exceed the purpose and limits of the present paper, I cannot provide a comprehensive comparison of the US-EU regulatory solutions (and similar problems they both suffer from) on this matter, although I share the anonymous reviewer's view that such comparison would indeed be useful.
} 
quantifiable (economic, monetary) and disregard non-quantifiable (social, cultural) factors. ${ }^{162}$ For this reason, Pedersen continues, application of the precautionary principle in some instances, lead[s] to confrontation with ideas of public participation, emphasis on social justice, and popular epidemiology - all ideas that are central to environmental justice.' ${ }^{163}$

For the European context more specifically, in their seminal study Pye and others wrote that:

[The impact assessment] approach [has been criticised because], in practice, the focus is principally on economic aspects, while non-economic aspects are usually framed in an economic way (e.g. social issues are typically reduced to employment considerations). Additionally, [impact assessments] on environmental policy proposals did not cover social aspects well, while 'non' environmental policy proposals tended not to cover environmental aspects well. ${ }^{164}$

Pedersen further argues that the principle of prevention likewise might fail environmental justice. The reasons include the dependence of preventive action on cost-benefit analysis, the latter being driven by market logic and inherently oriented toward preserving the status quo. ${ }^{165}$ In other words:

162 ibid, 35. Also, Ken Sexton, 'Socioeconomic and Racial Disparities in Environmental Health: Is Risk Assessment Part of the Problem or Part of the Solution?' (2000) 6(4) Human and Ecological Risk Assessment 571: "Interpreting risk assessment to include only "hard" quantifiable (or quantified) factors, and disregarding or marginalizing "soft" nonquantifiable (or not quantified) variables, has tended historically to preclude considerations of pertinent issues, such as social class, ethnicity, race, and culture' (emphasis added). A similar critique of impact assessment tools has been offered in Europe. For a general critique of the precautionary principle and its incoherence and impracticality, see Cass R Sunstein, Laws of Fear: Beyond the Precautionary Principle (CUP 2005).

163 Pedersen (n 161) 35. Pedersen then acknowledges that '[o]n the other hand, the part of the precautionary principle that emphasises a change in the burden of proof, notwithstanding the legal ambiguity of such assertions, can form part of the environmental justice advocate's toolkit'.

164 Pye and others (n 12) 32-33 (emphasis added, footnotes omitted).

165 Pedersen (n 161) 37: '[T]he principle carries with it a reliance on cost-benefit analysis. This is witnessed where the principle is qualified, as it often is, by reference to a particular harm being either "serious" or "significant" before action is taken. In such cases, the authority deciding whether preventive action is needed will have to weigh the probability of damage against the possible environmental, health and socio-economic benefits and costs. Often such use of cost-benefit analysis, and its reliance on willingness to pay principles, is considered to be at odds with environmental justice arguments' (footnotes omitted). See also Douglas A Kysar, 'Climate Change, Cultural Transformation, and Comprehensive Rationality' (2004) 31 Boston College Environmental Affairs Law Review 555 (noting the scepticism of environmentalists who claim that cost-benefit analysis makes environmental damage get lost in attempts to reduce it to monetary terms, and is thus inherently oriented toward the status quo). On the other hand, Pedersen (n 161) notes that 'cost-benefit analysis can actually work in favour of an environmental justice argument', echoing Cass Sunstein's argument that 'it is possible to adjust any cost-benefit analysis so that it takes 
What worries environmental justice advocates about cost-benefit analysis and the economic way of thinking is that it seems to give license to the tyrannization of minorities, as long as there is an increase in wealth. Thus, cost-benefit analysis and other economic instruments seem to open the door to the oppression of poor minorities (both in the ethnic and the political sense) for the benefit of the rich. ${ }^{166}$

Similarly, the polluter pays principle is implemented first and foremost with a market-focused rationale, most often to the disadvantage of the most-deprived groups and individuals. ${ }^{167}$

Finally, the principle of sustainable development is frequently at odds with environmental justice given that it places social equity on an equal footing with economic development and environmental protection. It has thus

been argued that the broad focus on environmentally friendly solutions in the name of sustainable development - for instance, in the production of housing and commodities - will lead to situations where sustainability only reinforces already existing patterns of social inconsistencies. $^{168}$

Therefore, for some authors the concepts of sustainable development and environmental justice are essentially antithetical. ${ }^{169}$

Moreover, other environmental mechanisms implemented through the EU secondary law that put into concrete form the above-mentioned environmental principles, such as the landmark emissions trading scheme, are often at odds with environmental justice. 'Cap-and-trade'

into account distributive problems' 38. See the works of Cass Sunstein that Pedersen references in his article: 'Lives, Life-years, and Willingness to Pay' (2004) 104 Columbia Law Review 205; 'The Arithmetic of Arsenic' (2002) 90 Georgetown Law Journal 2255; 'Selective Fatalism' (1998) 27(2) Journal of Legal Studies 799.

166 Shi-ling Hsu, 'On the Role of Cost-benefit Analysis in Environmental Law: A Book Review of Frank Ackerman and Lisa Heinzerling's Priceless: On Knowing the Price of Everything and the Value of Nothing' (2005) 35(1) Environmental Law 171, as quoted in Pedersen (n 161) 37 (emphasis added).

167 Pedersen (n 161) 42: The main problems with the polluter pays principle, from an environmental justice point of view, are the principle's focus on free-market ideals, which on an ideological level goes against certain aspects of environmental justice, and the ways in which the principle is best implemented - through taxes which have the potential to hit the already hard-done-by populations the hardest'. 'However', Pedersen adds, 'at the same time, the principle can be utilised to achieve central environmental justice goals - mainly of a fairer distribution of harms and costs from polluting activities, where it operates as a rule of liability'.

168 ibid, 43-44 (footnotes omitted).

169 JB Ruhl, 'The Co-Evolution of Sustainable Development and Environmental Justice: Cooperation, Then Competition, Then Conflict' (1999) 9(2) Duke Environmental Law and Policy Forum 161. 
schemes of this kind are usually a point of contention between environmentalists and environmental justice movements, since they relegate emissions regulation to the market and disregard the social conditions of those suffering immediately from those emissions. ${ }^{170}$

In sum, it remains far from obvious that the existing environmental principles are capable of guaranteeing environmental justice to EU citizens in general, let alone in the context of the EU centre-periphery divide. At best, these principles seem to be fit to "cover only a limited part of the notion of environmental justice.' ${ }^{171}$

Where all this leads is the only option that I have earlier identified as having the potential to address gaps between the EU centre and periphery through environmental redistributive policies, and that is the Treaty reference to environmental diversity and the unequal economic development of the EU regions. As it stands, it only introduces the procedural obligation (of questionable legal force) to 'take into account the diversity of environmental conditions in the various regions of the Union'. Notably, it fails to require - or to impose a 'hard' mandate to reach and achieve - substantively just outcomes in environmental matters in the disadvantaged parts of the EU. In my view, arguably the only way to bridge the environmental centre-periphery gap would be through the conceptualisation of the Treaties' provisions (Articles 191 and 192 TFEU) in explicit (and substantive) environmental justice terms, in order to effectuate even stronger redistributive policies in favour of the EU periphery. This reading is, moreover, reinforced by the listing in Article $3 \mathrm{TEU}$ of the fundamental objectives of the EU, where (in paragraph 3), right next to the Union's establishment of the internal market and 'work for the sustainable development of Europe based on [...] a high level of protection and improvement of the quality of the environment', one finds 'promot[ion] of social justice' and of 'economic, social and territorial cohesion, and solidarity among Member States.' ${ }^{172}$

170 Eli Keenea, 'Resources for Relocation: In Search of a Coherent Federal Policy on Resettling Climate-Vulnerable Communities' (2018) 48 Texas Environmental Law Journal 141: 'Some environmental justice groups have, for example, long objected to cap-and-trade policies aimed at reducing greenhouse gas emissions under the reasoning that these policies are likely to promote the continued operation of facilities emitting conventional pollutants primarily in poor and minority communities'. See also Lilly N Chinn, 'Can the Market Be Fair and Efficient? An Environmental Justice Critique of Emissions Trading' (1999) 26(1) Ecology Law Quarterly 80; Richard T Drury, Michael E Belliveau, Scott J Kuhn and Shipra Bansal, 'Pollution Trading and Environmental Injustice: Los Angeles' Failed Experiment in Air Quality Policy' (1999) 9(2) Duke Environmental Law and Policy Forum 231.

171 Vanheusden (n 156) 167.

172 I thank the anonymous reviewer for drawing my attention to the possibility of reading Articles 191-192 TFEU and Article 3 TEU 'in conjunction' to buttress the argument in question. 
The Treaties' environmental provisions in question should thus be operationalised as requiring differential treatment between the two groups of countries: although formally equal, Member States of the EU centre and periphery are substantively unequal in environmental matters, as I have previously shown. The root of the problem might be traced back to the 1990s: post-communist countries from Central and Eastern Europe were categorised in international environmental regimes (for example, the UNFCCC) as 'developed countries'. Although they did not fit the category of 'developing countries' either, it was unrealistic that just by placing them in an artificially constructed category of economically 'developed countries' they immediately matched the level of development or the historical environmental burden of Western European states. As a result, in Gonzalez's words, '[g]iven the economic disparities among states, formal equality [is likely to] exacerbate poverty and inequality'. ${ }^{173}$

Nowadays, insisting formalistically on these randomly created, yet 'reified', categories prevents differentiation between the differently situated (in environmental matters) countries of the EU centre and periphery. What could be introduced in EU environmental law to ensure substantive equality between the two groups of countries would follow the logic of asymmetric equality - something akin to the international law principles of 'special or differential treatment', ${ }^{174}$ such as 'common but differentiated responsibilities' (CBDR). ${ }^{175}$ This approach would demand EU decision-making processes to acknowledge the EU centre's disproportionate - historical and contemporary - contribution to environmental degradation, its superior capacities and resources (financial and technical) to address environmental problems, and the EU periphery's economic and ecological vulnerability (in comparison to the EU centre). ${ }^{176}$

173 Gonzalez (n 22) 88 (emphasis added).
174 ibid, 87-88: 'One important tool to mitigate North-South inequality is differential treat-
ment in international law. Norms of differential treatment in favour of Southern countries
are designed to redress historic inequities, and have been utilised in both international
economic law and international environmental law. While differential treatment has been
on the wane in international economic law since the early 1990s, it has been on the rise in
international environmental law. [...] [T]he principles that have arisen to promote differen-
tial treatment [are]: (1) special and differential treatment in international trade law; and (2)
common but differentiated responsibility in international environmental law. [...] Differen-
tial treatment seeks to narrow the gap between the colonisers and the formerly colonised by
providing more advantageous treatment to the latter' (footnotes omitted). 175 Lavanya Rajamani, Differential Treatment in International Environmental Law (OUP 2006).

176 Following the approach proposed by Gonzalez (n 22) 90-91: 'States differ in terms of their contribution to global environmental degradation, their vulnerability to environmental harm, and their capacity to address environmental problems. Northern proposals to protect the global environment without taking these differences into account have sparked scepticism in the global South. Indeed, Northern environmentalism was initially regarded as yet another effort to "kick away the ladder" and perpetuate Southern poverty by depriving the 
I expect this proposal to be regarded as radical or illusory. The answers that I anticipate might include some of the following.

One may immediately defend the current Treaty procedural requirement ('take into account') and regard any kind of substantive requirement for environmental justice as unnecessary with the following argument: EU environmental constitutional principles in synergy with just decision-making procedures established by the EU Treaties must render substantively just outcomes in environmental matters. This resembles the Rawlsian idea of a just constitution agreed upon by the social contractors, which establishes just procedures, whose operation ensures that the delivered substantive outcomes will be equally just. However, this account begs the question: what do the EU Treaties and the EU's established procedures reflect in terms of values and ideology? As argued by European CLS scholars, these values are dominantly market-centred and favour Member States of the EU centre. Moreover, legal rules and procedures reflect the balance of power existing at the moment of their adoption; they are, in a way, 'frozen politics' of the constitutional moment. ${ }^{177}$ For this reason, the entire environmental framework will most likely reflect the interests of the EU centre which dominated the creation of these principles, rules and procedures.

global South of the polluting technologies that the North had used to industrialise. [...] The principle of common but differentiated responsibility finds use in international environmental law to impose asymmetrical obligations on the North and the South in light of: (1) the North's disproportionate contribution to global environmental degradation; (2) the North's superior financial and technical resources; and (3) the South's economic and ecological vulnerability' (footnotes omitted). Something along these lines was seemingly attempted with the EU Burden Sharing Agreement, but with an uncertain outcome. See Johan Eyckmans, Jan Cornillie and Denise Van Regemorter, 'Efficiency and Equity in the EU Burden Sharing Agreement' (2002) KU Leuven, Centre for Economic Studies Energy, Transport \& Environment, Working Paper Series No. 2000-02 28: '[Having] investigated the EU Burden Sharing Agreement on carbon emission abatement that implements the EU's Kyoto commitment to reduce its greenhouse emissions by $8 \%$ compared to 1990 emissions by the compliance period 2008-2010 [...] [which, it was argued,] reconciles both cost efficiency and equity concerns $[\ldots]$ we have shown that even if one does not care about distributive justice, th[e] differentiation of abatement obligations does not go far enough. Most of the richer EU member countries should abate more, many poorer member states less (or should get an even more generous allowance)'; but see Per-Olov Marklunda and Eva Samakovlis, 'What Is Driving the EU Burden-sharing Agreement: Efficiency or Equity?' (2007) 85(2) Journal of Environmental Management 317 (arguing that both efficiency and equity featured prominently in reaching the agreement on the distribution of reduction targets for greenhouse gasses emissions between the Member States). See also Commission, 'Climate Action. Effort Sharing 2021-2030: Targets and Flexibilities', available at <https://ec.europa.eu/clima/ policies/effort/regulation_en> accessed 1 November 2019. I am grateful to the anonymous reviewer for pointing this issue out to me.

177 Perišin (n 39) 165: 'Legal rules and their application are a consequence of a balance of power at a particular moment. They are "frozen politics". Legal rules are a snapshot of political power and political will at the moment of their adoption' (footnotes omitted). 
Here, another objection may be that all EU Member States, including the peripheral ones, have fully consented to every aspect of EU law when expressing their intention to join the Union, in accordance with their respective constitutional rules. The response to this would be to look into the conditions of that consent and ask under what circumstances the EU periphery joined? First, these countries did not join the Union as equals to the countries of the EU centre. Most of the EU rules and procedures were imposed on them through the process of membership negotiations and strict conditionality that had to be complied with. The exchange between the 'old' and 'new' Member States in that respect was not free and mutual but unequal and one-sided. ${ }^{178}$ As such, the values and interests of the new members were not reflected in the constitutional setup that emerged following the enlargement. Therefore, not only were the starting positions in the EU unequal, but the established constitutional setup might further deepen the existing differences and inequalities. As Perišin and Koplewicz note, the centre-periphery gap 'is not just a consequence of the different starting positions at the moment of enlargement, but [...] EU law can actually accentuate the differences between Member States.' ${ }^{179}$

A further objection might continue as follows: if the system is so unjust, why do they (the peripheral states) not leave? If they remain, are they not repeatedly consenting to the constitutional framework and thus confirming its justness? This view simplifies the voluntariness of remaining in the EU and not objecting to the existing rules: if one of the most powerful countries of the EU centre (the UK) is currently facing enormous difficulties in implementing its withdrawal from the Union, how easy would it be for some peripheral states to do so? In this context, invoking the concept of consent would serve to legitimise the established hierarchies of power, the dominance of the rule-makers over the ruled (and possibly the latter's exploitation). Let us remind ourselves here of the Gramscian view that hegemony work[s] in many ways to induce the oppressed to accept or "consent" to their own exploitation and daily misery'. ${ }^{180}$

By extension, I submit the same would apply to environmental principles and procedures. There, we have unequal input between the centre and periphery; hence, the output will be unequal too. A gap between the environmental values and interests of the EU core and periphery is

\footnotetext{
178 Siniša Rodin, 'Discourse and Authority in European and Post-Communist Legal Culture' (2005) 1 Croatian Yearbook of European Law and Policy 1.

179 Perišin and Koplewicz (n 21) XIV (referencing the works of Daniela Caruso and Damjan Kukovec) (footnotes omitted).

180 Gottlieb, Bix, Lytton and West (n 16) 632.
} 
increasingly becoming apparent. ${ }^{181}$ So, simply by having formally just principles and procedures in the EU, without explicitly inserting substantive requirements for environmental justice, does not ensure that environmental justice will be delivered for every Member State equally. The insufficiency of 'the procedural approach only' has already been recognised in the USA. ${ }^{182}$ To expect otherwise is to hold strongly to the formalist understanding of equality, law and justice, formalism which dominates the European legal culture. ${ }^{183}$ (Recall that earlier I have similarly criticised the formalistic approach in the procedural and corrective dimensions of environmental justice in the EU.) This is the classic approach of legal liberalism, its 'utopian moment': pretending that there is an initial state of equality, and making rules as if there was indeed such a state, in order for those rules to lead there, that is, to a state of genuine substantive equality. ${ }^{184}$

\section{Concluding remarks}

In this paper, I have adopted a different analytical approach from what is usually attempted in European legal scholarship: analysing environmental injustices within individual states in Europe or observing Europe's role internationally, as part of the global North, in environmental injustices against developing countries. Instead, I have framed the discussion about environmental justice in the EU in terms of the divide between its centre (Member States of Western and Northern Europe) and periphery (Member States of Central and Eastern Europe). I have identified distributive, procedural and corrective injustices that make the EU periphery, although less responsible for historical and contemporary environmental harms in Europe, bear greater environmental burden than the EU centre, in addition to having less influence over environmental decision-making. I have used ideas that have already emerged (most-

\footnotetext{
181 Perhaps most notable, at least recently, is the bloc's divide on coming up with a climate change strategy for the Paris Agreement Conference of Parties in 2018. See Jean Chemnick, 'UN Talks Deliver "Fragile Balance" on Paris rules' (Environment \& Energy News, 17 December 2018) available at <www.eenews.net/climatewire/stories/1060109775> accessed 1 November 2019.

182 Lynn (n 1) 240: 'Procedural laws cannot meet environmental justice goals of equal concern and respect'.

183 Pieter-Augustijn Van Malleghem, 'Reflections on European Legal Formalism' in Tamara Perišin and Siniša Rodin (eds), The Transformation or Reconstitution of Europe. The Critical Legal Studies Perspective on the Role of the Courts in the European Union (Hart Publishing 2018) 203.

184 Remarks by Professor Catharine A MacKinnon during a lecture at the University of Michigan Law School (April 2019). See also MacKinnon (n 138) 45: 'Because a fundamental dynamic of the European Union revolves around the handling of differences among Member States, adjudication of equality issues on a [Union] level often confronts cultural assumptions and raises methodological as well as substantive equality issues' (emphasis added).
} 
ly) in US scholarship, in the context of environmental justice, comparative constitutionalism and federalism studies, and, more generally, in the critical analysis of the (re)distributive effects of law and the identity critique of law. Finally, I have reflected on some possible avenues for integrating environmental justice concerns into the EU legal and institutional framework in order to better address the centre-periphery gap and mitigate existing regional inequalities. Here, I want to offer a few more general thoughts about this.

First, it is not immediately obvious for what reason and how - that is, through which instruments and at which levels of governance - to modify laws and policies after environmental injustice in the EU has been identified at this level. ${ }^{185}$ Due to subsidiarity issues and the division of competences between the EU and the Member States, the Union authorities can only address the supranational (and not purely national) instances of environmental injustice. ${ }^{186}$ So, some imaginative rethinking will be inevitable. As Pedersen observes, 'environmental justice as a concept provides a framework for the probing of established environmental law and policy norms and concepts. ${ }^{187}$

For this to happen, purely formal amendments of relevant laws and strategies would plainly be inappropriate on their own. ${ }^{188}$ A conceptual move from sustainable development towards differential treatment of the

185 Paul Mohai, David Pellow and J Timmons Roberts, 'Environmental Justice' (2009) 34 Annual Review of Environment and Resources 407: '[The] reason environmental justice studies are controversial is that it is not immediately obvious what should be done after an injustice has been documented: Addressing environmental injustice with public policy could involve complex and expensive local, national, or perhaps even global interventions'. Also, in the EU context, Perišin and Koplewicz (n 21) XVII: 'Regardless of whether any inequality was caused or aggravated by the EU or whether it was caused by other developments, the question remains about what the EU should be doing to correct it'.

186 Pye and others (n 12) 32: 'When discussing the strategic policies and processes at the EU level, it is important to bear in mind the competencies and role of the European Commission with respect to its Member States. These are governed by [EU] treaty and - amongst others - the principle of subsidiarity. From the perspective of the relationship between the EU and its Member States, therefore, decisions should be taken at the Member State level, unless EU level action is more appropriate. The role of the Commission is set out in the Treaty and varies between policy areas. For example, while a large proportion of Member States environmental policies have their origins in EU environmental legislation, most aspects of social policy remain the competence of Member States. Hence, the EU has only limited powers in the field of social policies, including those aimed at reducing social exclusion. This is reflected in the fact that the measures to take forward the social exclusion agenda focus on coordination of Member State approaches, whereas action on the environment often takes the form of legislation' (footnotes omitted).

187 Pedersen (n 161) 49.

188 Steger and Filcak (n 159) 52: '[T]he formal declaration of legal principles is only one step in a series of steps for addressing the roots and effects of the unequal distribution of adverse environmental impacts'. For some examples of the possible policy and legal amendments ('preambulatory and/or substantive'), see Steger (n 32) 52. 
EU centre and periphery, similar to what we have in international law, would be warranted (as I have argued in the previous section). More specifically, some kind of tools for assessing the distributional impacts of the EU environmental regulations and policies between different Member States would also be necessary, but not sufficient in themselves. ${ }^{189}$ Regarding the institutional actors, the solution should probably not be looked for on the Luxembourg benches but rather in the political process, since the Court of Justice - for many European legal scholars, a traditional 'last resort' protector of rights - champions, as we have seen, restrictive and regressive interpretations in matters bordering environmental justice.

On the other hand, the law might not offer the answer at all. Even worse - it might colonise the struggle for environmental justice. ${ }^{190}$ If so, what could be left for the EU's 'integration through law' approach? ${ }^{191}$ Radical solutions, such as 'a bold rethinking of the dominant economic paradigm'192 would seem counterintuitive and antithetical to the raison d'être of the EU market-centred integration project. This would be off the

\footnotetext{
189 Pye and others (n 12) 33: '[T]he European Commission and national, or regional administrations as appropriate, should develop guidance and other tools, as necessary, on assessing distributional impacts (e.g. through Equality Impact Assessments), and require this to be followed if there is the potential that a proposed policy might have adverse impacts on vulnerable groups'.

190 For a powerful, critical assessment of the (in)compatibility between (legal) environmentalists and environmental justice movements in the USA that in many ways still feels relevant today, and whose gist might equally be applied to the supranational context, see Luke W Cole, 'Foreword: A Jeremiad on Environmental Justice and the Law' (1995) 14 Stanford Environmental Law Journal xiii-Xv: '[T]he field of environmental justice is being colonized by lawyers and legal groups. [...] When the legal groups get hold of the concept of environmental justice, they redefine it to fit their focus and orientation, although they are in direct opposition to the essence of environmental justice. The "answer" to environmental racism becomes laws and litigation, rather than community empowerment in local decisionmaking. [...] What began as a vibrant community movement gets redefined as just another issue for which we need legislation or a new legal strategy. Such redefinition, which reinforces the existing social/political hierarchy by favoring legal "expertise" over community action, is completely at odds with the environmental justice movement. [...] The colonization of the movement by legal groups dilutes the movement's premises, taking the power of environmental justice as a potentially transformative social movement and turning it into "just another" issue among the many on which the legal groups are working. In a very real way, the legal groups are re-creating one of the roots of environmental injustice: the making of decisions by people not affected by those decisions. Thus, on both the theoretical and practical levels, the entrance of legal groups into the environmental justice field is in many ways a detriment to the movement, blunting its ideological edge and diverting its limited resources'.

191 Loïc Azoulai, '“Integration through Law" and Us' (2016) 14(2) International Journal of Constitutional Law 449.

192 Gonzalez (n 22) 85: '[E]nvironmental justice calls for a bold rethinking of the dominant economic paradigm so as to promote economic and social development while respecting the planet's biophysical limits'.
} 
table, I believe. Nevertheless, some things could perhaps be attempted from within the system: it seems that there is still some room for the better integration of substantive environmental justice principles and objectives in both social and environmental policies and regulations in the EU. ${ }^{193}$

Currently, it remains highly questionable whether the existing environmental framework in the EU is capable of delivering the two-pronged objective: safeguarding the environment (in Europe and globally) and the most vulnerable communities (nationally, regionally, globally) that suffer from environmental degradation. ${ }^{194}$ Or whether diverging national environmental and social traditions in Europe could ever converge into a genuine EU environmental justice approach. ${ }^{195}$ Whether a genuine cross-policy integration of environmental justice in the EU would ever be politically feasible is another issue: it would inevitably necessitate big redistributive measures that would themselves create new winners and losers. ${ }^{196}$ This is not a purely technocratic call, but an ideological and

\footnotetext{
193 Pye and others (n 12) made the following recommendations (among others): 'The concept of environmental justice should be adopted as a guiding principle for policy development at the European level and across all Member States as a means of addressing social concerns within environmental policy. [...] Environmental inequalities should be considered in the design and implementation of policy through the impact assessment process at the European, national and local levels' (v). They further argued that '[i]t is important that the interlinkages and interactions between environmental and social policy are recognised in order to avoid conflict between policy objectives and to contribute to the development of better and mutually reinforcing policies for both policy areas. These policy areas are deeply interlinked; environmental policy impacts on society in different ways while social factors affect environmental quality, for example through patterns of consumption. Therefore, there is a need for policy makers to take an integrated approach, recognising where the policy areas interface, and considering policy design and implementation that is mutually advantageous' (ii). Steger (n 32) 51, added that '[s]trengthening EU laws to promote environmental justice could include making linkages between EU anti-discrimination and EU environmental law and mainstreaming environmental justice themes and considerations into all EU policies (social, development, health sectors, etc.) and especially environmental laws'. Laurent (n 13) 1849, similarly remarked that 'environmental policies should be embedded in and not artificially isolated from social policies, so that true "social-ecological policies" can be designed and implemented and become building blocks of a fairer European welfare state'.

194 Chaitanya Motupalli, 'Intergenerational Justice, Environmental Law, and Restorative Justice' (2018) 8(2) Washington Journal of Environmental Law and Policy 360: 'Although it is a remarkable achievement, we have seen that existing environmental law has considerable limitations, and the hope of using it to fix environmental problems is rather slim'.
}

195 Laurent (n 13) 1849: '[...] the possibility to conceive not only a European approach, distinct from the US approach, but an integrated or even harmonized European approach and possibly a European Union approach to environmental justice, bringing together the different (young) national traditions in this domain of public action. The problem here is the fragmented nature of those national traditions' (footnotes omitted).

196 Motupalli (n 194) 340: '[E]nvironmental law [...] has a "tremendous redistributive thrust”. By statutory terms, regulations, and enforcement, environmental law imposes 
value-laden one - politically perhaps the hardest call of all. As Walker warns,

environmental decision making is not just a technocratic process, there is an inevitable normative politics involved. Incorporating distributional analysis of winners and losers, benefits and burdens, might make a key part of this normative politics more explicit, but in so doing the result may be to emphasise difference and disagreement rather than enable negotiation and consensus building. ${ }^{197}$

In the context of the EU centre-periphery divide, the traditional EU technocratic outlook in environmental decision-making would need to recognise the normative, political part to it. ${ }^{198}$ This would come with an even greater redistribution of wealth from the EU centre to its periphery. However, it seems highly unlikely that in the current state of EU integration anything like this would be an acceptable alternative. It would demand unprecedented solidarity of the citizenry in Member States of the centre with their counterparts in the EU periphery; the former's acceptance to lose in order for the latter to gain. To paraphrase Žižek, a contemporary critical philosopher (originally from the EU periphery): 'Redistribution [to achieve environmental justice] hurts'. ${ }^{199}$ Contrary to what a liberal-centrist, status quo-preserving position would have, there

costs and benefits on various stakeholders, and in the process creates winners and losers' (footnotes omitted).

197 Gordon Walker, 'Environmental Justice, Impact Assessment and the Politics of Knowledge: The Implications of Assessing the Social Distribution of Environmental Outcomes' (2010) 30(5) Environmental Impact Assessment Review 317 (emphasis added).

198 This is precisely what CLS scholars urge for the law in general: that it can never be technocratic and objective but that it embodies important social and normative elements. So, when it is claimed that the law is neutral or technical, this usually obfuscates and conceals its biased background - the ordering of society, the political decision, or in Holt's words the 'tilt' in favour of the dominant ruling elite and its established interests. See Wythe Holt, 'Tilt' (1984) 52(2) George Washington Law Review 280.

199 Žižekian 'liberation hurts' appears in the discussion of his The Fragile Absolute: Or, Why is the Christian Legacy Worth Fighting For? (Verso Books 2000) in "Liberation Hurts", An Interview with Slavoj Žižek by Eric Dean Rasmussen' (Electronic Book Review, 7 January 2004) available at <https://electronicbookreview.com/essay/liberation-hurts-an-interview-with-slavoj-zizek/> accessed 1 November 2019, where Žižek also says: '[L]iberation hurts. What I don't buy from liberals is this idea of, as Robespierre would have put it, "revolution without revolution", the idea that somehow, everything will change, but nobody will be really hurt. No, sorry, it hurts'. It should be mentioned that this idea of solidarity and (some) redistribution in favour of the EU periphery has recently been shyly entertained in the context of negotiations of the EU's 2050 climate strategy, when the idea of 'Energy Transition Fund/Just Transition Fund' popped up. See Sam Morgan, 'Climate Cash Cow: Where EU Countries Can Get Their Funding' (EURACTIV, 18 June 2019) available at <www. euractiv.com/section/climate-environment/news/climate-cash-cow-where-eu-countriescan-get-their-funding/> accessed 1 November 2019; Sam Morgan, 'The Curious Case of the Missing Fund' (EURACTIV, 22 October 2019) available at <www.euractiv.com/section/ energy-environment/news/the-brief-the-curious-case-of-the-missing-fund/> accessed 1 November 2019. 
is arguably no way of righting the (historical) wrongs without someone suffering (some) injustice in the process.

So, given the contemporary political zeitgeist and the fragility of European demoi-cracy, ${ }^{200}$ the ideal of EU nations being 'united in diversity' while approaching the 'ever closer Union' around the concept of environmental justice, unfortunately, seems unattainable. How seriously, if at all, this acknowledgment would affect the future of European integration remains an open question. ${ }^{201}$

\section{(9) (1) $(\Theta \Theta$}

This work is licensed under the Creative Commons Attribution - Non-Commercial - No Derivatives 4.0 International License.

Suggested citation: D Petrić, 'Environmental Justice in the European Union: A Critical Reassessment' (2019) 15 CYELP 215

\footnotetext{
200 For more details on this notion, see Kalypso Nicolaidis, 'The Idea of European Demoicracy' in Julie Dickson and Pavlos Eleftheriadis (eds) Philosophical Foundations of European Union Law (OUP 2012) 247.

201 Perišin and Koplewicz (n 21) XXII: 'For the future of European integration, it is vital for the EU to address two questions. First, how much inequality can be attributed to the effects of law in the current set-up of the EU system (ie can Brussels or Luxembourg be blamed for it) or, instead, is inequality the result of different causes (eg globalisation, technical progress)? Second, what can the EU do to address inequalities resulting from EU integration or from other causes, and to make the positive sides of integration, including its contribution to equality, more visible to citizens?'
} 